\title{
Sosyal Medyada Otel İşletmelerine Yönelik Yorumların Müşsteri Memnuniyeti ve Memnuniyetsizliği Açısından Analizi ${ }^{1}$
}

\author{
Analyses Of Social Media Reviews About Hotel Enterprises In Terms Of Customer \\ Satisfaction And Dissatisfaction
}

Fatih Ercan*

$\ddot{O} Z$

Sosyal medya, günümüzde işletmeler ve bireyler tarafindan yaygın şekilde kullanılan bir iletişim aracıdır. Müşteriler, otel işletmelerinin kurumsal sosyal medya hesapların takip etmekte ve yaşadıkları hizmet deneyimleriyle ilgili memnuniyet ve memnuniyetsizliklerine ilişkin yorumlar otel işletmeleri ve diğer kişilerle paylaşmaktadırlar. Bu araştırmanın amacı, otel işletmelerinin kurumsal Facebook sayfalarına yapılan yorumlarda müşteri memnuniyeti ve memnuniyetsizlik unsurların tespit etmektir. Marmaris'te bulunan 5 yıldılı otel işletmelerinin kurumsal Facebook sayfalarına yapılan 460 adet müşteri yorumu içerik analizi yöntemi kullanılarak analiz edilmiştir. Araştırma sonuçlarına göre, müssteri yorumlarında en sık ifade edilen memnuniyet ana unsurlart strayla personel, yiyecekler, diğer, misafir odalarl, otel olanaklarl, hizmet kalitesi, konum ve içeceklerdir. Yiyecekler, personel, diğer, hizmet/ekipman eksiklikleri, temizlik ve içecekler müşteri memnuniyetsizliğine ilişkin tespit edilen ana unsurlardır.

\section{ANAHTAR KELIMELER}

Müşteri Memnuniyeti, Müşteri Memnuniyetsizliği, Otel İşletmeleri, Müşteri Yorumları, İ̧̧erik Analizi.

\begin{abstract}
Social media is a widely used communication tool by companies and individuals nowadays. Customers are follow the corporate social media accounts of hotel enterprises and share service experience reviews wtih hotel and other people about satisfaction and dissatisfaction. The aim of this study to determine the customer satisfaction and dissatisfaction elements on reviews which commented on corporate social media accounts of hotel enterprises. 460 customer reviews on corporate social media accounts of five star hotels in Marmaris were analyzed by content analysis method. According the research results, the most frequently expressed satisfaction core elements on customer reviews are respectively staff, foods, other, guest rooms, hotel facilities, service quality, location and drinks. In addition to this, foods, staff, other, servicelequipment inadequacies, cleanliness and drinks are the core customer dissatisfaction elements.
\end{abstract}

\section{KEYWORDS}

Customer Satisfaction, Customer Dissatisfaction, Hotel Enterprises, Customer Reviews, Content Analysis

\begin{tabular}{|c|c|c|}
\hline \multicolumn{2}{|c|}{$\begin{array}{c}\text { Makale Geliş Tarihi / Submission Date } \\
24.05 .2019\end{array}$} & \multicolumn{1}{c|}{$\begin{array}{c}\text { Makale Kabul Tarihi / Date of Acceptance } \\
17.07 .2019\end{array}$} \\
\hline \multirow{3}{*}{ Atıf } & $\begin{array}{l}\text { Ercan, F. (2019). Sosyal Medyada Otel İşletmelerine Yönelik Yorumların Müşteri Memnuniyeti ve Memnuniyetsizliği } \\
\text { Açısından Analizi. Selçuk Üniversitesi Sosyal Bilimler Meslek Yüksekokulu Dergisi, 22 (2), 552-571. }\end{array}$ \\
\hline
\end{tabular}

\footnotetext{
${ }^{1}$ Bu çalışma, 18-20 Nisan 2019 tarihinde II. Uluslararası İşletme Ekonomi ve Pazarlama Kongresinde sunulan ve özet metin kitabında yer alan “Otel İşletmelerine Yönelik Sosyal Medya Yorumlarında Müşteri Memnuniyeti Unsurlarının İncelenmesi” isimli çalışma genişletilerek oluşturulmuştur. * Doktor Öğretim Üyesi, Zonguldak Bülent Ecevit Üniversitesi, Kdz. Ereğli Turizm Fakültesi, Turizm işletmeciliği Bölümü, fatih.ercan@ beun.edu.tr, ORCID: 0000-0001-6469-3000
} 


\section{GíRiş}

Müşteri memnuniyeti, gerek pazarlama uygulamalarında gerekse ilgili akademik alanyazında uzun yıllardır araştırma konusu olan önemli bir kavram olarak dikkat çekmektedir. Her iş alanı ve boyuttaki işletmenin başarısında anahtar faktör olan bu kavram, müşteri bağlılı̆̆ının oluşturulması ve rekabet avantajı elde edilmesinde kritik bir rol oynamaktadır. Bu bakımdan, ulusal ve uluslararası alanda yoğun bir rekabet ortamı içerisinde faaliyetlerini sürdüren otel işletmeleri açısından müşteri memnuniyetine ve memnuniyetsizliğine neden olan unsurların anlaşılması kaçınılmaz bir zorunluluk olarak değerlendirilebilir.

Son yıllarda hızla gelişen internet teknolojilerinin bir ürünü olarak yakın geçmişte ortaya çıkan sosyal medya, kişiler arasında kullanımı oldukça yaygın olmakla birlikte işletmeler de bu yeni iletişim ortamında yer almakta ve faaliyetlerini burada sürdürmektedirler. Leung ve diğ. (2013), sosyal medyanın son yıllarda turizm endüstrisi içerisindeki konaklama işletmelerinin faaliyetlerini önemli derecede etkileyen bir "mega trend" olduğunu belirtmektedirler. Turizm işletmelerinin faaliyetlerinde ve yönetiminde sosyal medyanın etkilerine vurgu yapan yazarlar, işletmelerin tutundurma faaliyetlerinde ve müşterileriyle olan iletişimlerinde sosyal medyayı önemli bir araç kullandıklarını belirtmektedirler. Eryılmaz ve Zengin (2014: 148-149), işletmelerin faaliyetlerini günümüzde internet sitelerinden sosyal medyaya taşıdıklarını, bu mecranın hedef kitleyi tanıma, iletişim kurma ve onlarla yakınlık sağlamaya imkan vermesi gibi sebeplerle farklı sektörlerden çok sayıda işletme gibi konaklama işletmelerini de bu alana çektiğini ifade etmektedirler. Yılmazdoğan ve Özel (2014:38) de, benzer biçimde, konaklama işletmelerinin sosyal medyada kurumsal kimlikleriyle yer aldıklarını, pazarlama hedeflerini gerçekleştirme, karlılıklarını artırma ve müşteri memnuniyeti sağlamak amacıyla etkili bir araç olarak sosyal medyayı kullandıklarından söz etmektedirler.

Günümüzde otel işletmeleri, Facebook, Twitter, YouTube ve İnstagram gibi kişiler arasında sıklıkla kullanılan sosyal medya mecralarında yer almakta, mevcut ve potansiyel müşterileri ile buradan iletişime geçmektedir. Otel işletmeleri, kurumsal sosyal medya sayfalarında otel hakkında bilgiler, duyurular, fotoğraflar ve videolar gibi unsurların yanı sıra işletmenin sayfasını takip eden müşterilerin otel hakkındaki yorumlarına ve değerlendirmelerine de yer vermektedirler. Burada müşteriler aldıkları hizmeti çeşitli ölçütlere göre değerlendirebilmekte, tatil deneyimleriyle ilgili memnuniyet ve memnuniyetsizliklerini yazarak otel işletmesi ve diğer müşterilerle paylaşabilmektedirler.

İlgili alanyazın incelendiğinde (Li ve diğ., 2013; Kızılırmak ve dĭğ., 2015; Dinçer ve Alrawadieh, 2017; Bilgihan ve diğ., 2018) hem otel işletmelerinde hem de diğer turizm işletmelerinde müşteri memnuniyeti ve memnuniyetsizliği unsurlarının araştırılmasına yönelik çalışmalarda sosyal medyada yapılan tüketici değerlendirmelerinden sıklıkla yararlanıldığı dikkat çekmektedir. Erdem ve Yay (2017) tarafindan Antalya il merkezindeki birinci sınıf restoranlara ilişkin TripAdvisor.com'da yer alan olumsuz müşteri yorumlarının sınıflandırılması amacıyla bir çalışma gerçekleştirilmiştir. İçerik analizi yöntemi kullanılarak yapılan çalışmada, restoran müşterilerinin yiyecek içecek, servis, fiyat, hizmet ortamı ve menüyle ilgili şikayet ettiği sonucuna ulaşılmıştır. Otel işletmelerinde müşteri memnuniyeti unsurlarını belirlemeye yönelik yapılan bir çalışmada, TripAdvisor.com'daki çevrimiçi müşteri yorumları içerik analizi yöntemiyle analiz edilmiştir. Çalışma sonucunda, otel işletmelerinde ulaşım kolaylığ 1 , yiyecek ve içecekler, yatak, resepsiyon hizmetleri, oda boyutu ve dekorasyon gibi unsurların müşteri memnuniyeti açısından önemli olduğu ortaya konulmuştur (Li ve diğ, 2013).

Otel işletmeleriyle müşteriler arasındaki ilişkilerin yoğun bir biçimde yaşandığı sosyal medya aracı olan Facebook (Cinnioğlu ve Boz, 2015: 250) üzerindeki değerlendirmelerin analiz edilerek müşteri memnuniyetine ve memnuniyetsizliğine ilişkin unsurları belirlemek ve otel işletmeleri için çıkarımlarda bulunmak bu araştırmanın temel amacını oluşturmaktadır. Otel işletmelerinin kurumsal Facebook sayfalarında müşteri memnuniyeti ve memnuniyetsizliğine yönelik değerlendirmelerden elde edilecek veriler, otel işletmelerinin faaliyetlerinin başarısı açısından önem taşıyan bir husus olarak değerlendirilebilir.

\section{1.İLGILİ LITTERATÜR}

\subsection{Müş̧teri Memnuniyeti ve Memnuniyetsizliği Kavramları}

21. yüzyılda teknolojide meydana gelen gelişmeler, artan iletişim olanakları, ulaşım aracı alternatiflerindeki artış gibi faktörler işletmeler arası rekabeti artırmaktadır. Bununla birlikte, yaşanan yoğun rekabetin ulusal sınırları aştı̆̆ı, uluslararası bir boyut kazandığı görülmektedir. Bu rekabet ortamında varlıklarını devam ettirme istek ve arzusunda olan işletmelerin, müşterileriyle ilişkilerini geliştirme, hizmet kalitesini artırma ve nihayetinde müşteri memnuniyeti sağlama yönündeki faaliyetlerine daha fazla önem verdikleri görülmektedir. $\mathrm{Bu}$ sebeple, müşteri memnuniyeti ve memnuniyetsizliği, işletmelerin devamlılığ ve başarısı açısından üzerinde önemle durulması gereken kavramlar olarak dikkat çekmektedir. 
Müşteri memnuniyetini, özellikle pazarlama alanında sıklıkla üzerinde durulan ve geçmişten günümüze akademik alanda çok sayıda çalışmanın yapıldığı bir konu olarak değerlendirmek mümkündür. Bu kavrama ilişkin çok sayıda tanım bulunmakla birlikte, bunların içerik olarak birbirine yakın ve benzer tanımlamaların olduğu görülmektedir. Yapılan bir tanıma göre müșteri memnuniyeti, bir ürünün tüketiminden sonra, o ürüne yönelik tüketim öncesi beklentiler ile ürünün gerçek performansı arasındaki algılanan farka yönelik tüketici reaksiyonudur (Day, 1984: 496). Diğer bir tanımla memnuniyet, tüketicilerin, tüketim deneyimleri sonucu elde ettikleri çıktıların beklentilerini karşılama ya da karşılamama durumuna gösterdikleri tepkidir (Oliver, 1999:34). Burada, tüketim deneyiminin müşteri beklentileriyle örtüşmesi durumu memnuniyet oluştururken, tüketim deneyiminin müşteri beklentilerinin altında gerçekleşmesi ise memnuniyetsizlik durumu oluşturmaktadır. Müşteri memnuniyetine ilişkin diğer bir güncel tanıma göre ise, bir ürün ya da hizmete yönelik satın alma sonrası yapılan tüketici değerlendirmeleri sonucu gerçekleşen duygusal tepkilerdir (Prasadh, 2018: 179). Bu tanımlamalardan hareketle müşteri memnuniyeti ve memnuniyetsizliğini, bir ürün ya da hizmeti satın alma sonrası tüketicilerin beklentilerini karşılama veya karşılamama durumuna göre oluşan bir duygusal tepki olarak değerlendirilmek mümkündür.

İşletmeler tarafindan sunulan ürün ve hizmetlerin müşteri beklentilerini karşılaması veya beklentilerin ötesine geçmesiyle ilgili bir kavram olarak müşteri memnuniyeti (Rashed ve diğ., 2018: 24), müşterilerin satın aldığı bir ürünün beklentilerini karşılamasıyla ya da ürünün müşterinin bu istek ve beklentilerinin ötesine geçmesiyle sağlanır. Her iki durumda da müşteri istek ve beklentilerinin minimum düzeyde gerçekleşmesi ve bazı durumlarda bu beklentilerin ötesine geçilmesi söz konusudur (Çelik, 2012: 33-34). Oliver (1993: 418419), tatmin edici bir satın alma deneyiminin, tekrar satın alma davranışına neden olabilecek bir ürüne yönelik tüketici ilgisinin devamlılığı açısından önemli bir gereklilik olduğunu belirtmekte ve müşteri memnuniyetine yönelik çalışmaların önem taşıdığını belirtmektedir. Yazar, tüketicilerin bir ürüne yönelik performans algılarını tüketim öncesi beklentilerle karşılaştırdıklarını, bu karşılaştırma sonucunda beklenti onaylamama durumunun memnuniyet kararlarında önemli bir etkiye sahip olduğunu belirterek beklenti onaylamama kuramıyla müşteri memnuniyetini açıklamaktadır. Dolayısıyla, tüketicilerin bir ürün ya da hizmeti satın alma öncesi sahip olduğu beklentileri, ürün ya da hizmetin performansının karşılayıp karşılamamasının müşteri memnuniyeti ve memnuniyetsizliğinin oluşmasında kritik bir öneme sahip olduğu ifade edilebilir.

\subsection{Otel İşletmelerinde Müşteri Memnuniyetinin Önemi ve Memnuniyet/Memnuniyetsizlik Unsurları}

Turizm endüstrisinin temel unsurlarından biri olarak otel işletmeleri, 7/24 hizmet sunumunun gerçekleştiği, müşteri-çalışan arasındaki ilişkilerin oldukça önemli olduğu ve rekabetin yoğun bir şekilde yaşandığ 1 işletmelerdir. Müşteri memnuniyetini sağlayarak rekabette üstünlük sağlama çabası içerisindeki otel işletmeleri, bu unsuru faaliyetlerinin odak noktasına koymakta, müşterilerini en yüksek düzeyde memnun etmeye çalışmaktadırlar. Müşteri memnuniyeti ve memnuniyetsizliğine yönelik unsurların neler olduğunun anlaşılması, müşterilerin beklentilerine uygun hizmetin sunulabilmesi ve tatmin duygusunun artırılması açısından önem taşımaktadır.

Çelik (2012: 33-34), hizmet sektöründe müşteri memnuniyetinin, hizmetin sunumu ve tüketimi esnasında, müşterilerin beklentilerinin ve isteklerinin karşılanması ile sağlanabildiğini, bununla birlikte memnuniyetsizlik ya da memnuniyetin, hizmet sunumunda hemen ortaya çıkan bir durum olduğunu belirtmektedir. Yazara göre, müşteri tüketim süreci sonucunda ya memnun ya da kızgın bir şekilde işletmeden ayrılmakta, kızgın ayrılmasının temelinde isteklerinin/beklentilerinin karşılanamaması yatmakta ve bu da müşteri memnuniyetsizliğine neden olmaktadır. Bulut (2011: 389), özellikle hizmet sektöründe müşteri memnuniyeti kavramının daha fazla ön plana çıktığını, hizmet sektöründeki otel işletmelerinin de müşterilerini en üst düzeyde memnun etme isteğinde olduğunu belirtmektedir. Yazar, müşteri memnuniyeti sağlamaya yönelik çabaların en önemli nedeninin müşterilerin aynı oteli tekrar tercih etmesini sağlamak olduğunu belirterek müşteri sadakati oluşturmada memnuniyetin önemine işaret etmektedir. Cengiz Mutlubaş ve Soybalı (2017:4), bu görüşü destekleyerek, işletmelerin yeni müşteri elde etmelerinin maliyetli olduğuna, yeni müşteriler kazanmak yerine mevcut müşterilerin memnuniyet düzeylerini yüksek tutarak sadakatlerini kazanma yoluna gitmelerinin önemine vurgu yapmaktadırlar. Yazarlar, müşteri memnuniyeti ile müşteri sadakati arasında pozitif yönlü kuvvetli bir ilişkiye dikkat çekmekte, otel işletmelerinde konukların memnuniyet düzeyleri arttıkça sadakatlerinin de arttı̆̆ını belirtmektedirler.

Müşteri sadakatinin sağlanarak otel işletmelerinin varlıklarını devam ettirmeleri ve karlılıklarını sürdürebilmeleri açısından müşteri memnuniyeti konusu kritik bir öneme sahiptir. Bu sebeple, ilgili alanyazın incelendiğinde, otel işletmelerinde müşteri memnuniyeti ve memnuniyetsizliği unsurlarının tespitine yönelik çalışmaların sıklıkla yapıldığını görmek mümkündür (Sim ve diğ., 2006; Özer ve Günaydın, 2010; Bulut, 2011; 
Berezina ve diğ, 2016; Cengiz Mutlubaş ve Soybalı, 2017; Shah ve diğ., 2018). Özer ve Günaydın (2010) tarafından Marmaris bölgesindeki otel işletmelerinde gerçekleştirilen araştırmanın sonuçlarına göre, personelin güler yüzlü olması, kayıt işlemlerinin hızı ve bilgilendirme, çıkış işlemlerinin hızı, yemeklerin kalitesi, çeşitliliği, temizlik, personelin ilgisi gibi unsurlar müşteri memnuniyetinin sağlanmasında en önemli unsurlar olarak dikkat çekmektedir. Sim ve diğ. (2006) tarafından otel işletmelerinde müşteri memnuniyeti unsurlarının tespitine yönelik yapılan araştırmada, çalışanlar tarafından sunulan hizmetin kalitesi, çalışanların müşteri ihtiyaçlarını karşılamadaki yeterlilikleri, otelin mimari dizaynı, dekoru ve atmosferi, otelin konumu, alışveriş ve araç park yeri olanakları ile odalarda sunulan imkanların müşteri memnuniyetinde önemli unsurlar olduğu ve bunların müşteri sadakati üzerinde olumlu etkisi olduğu sonucuna ulaşıldığı görülmektedir.

Cherapanukorn ve Charoenkwan (2017) tarafindan Chiang Mai, Tayland'daki otel işletmelerine ilişkin TripAdvisor'da yapılan çevrimiçi müşteri yorumlarında müşteri memnuniyeti unsurlarının tespitine yönelik sözcük bulutu tekniği ile analiz gerçekleştirilmiştir. Çalışmada, otel olanakları, oda ve yatak temizliği, dekorasyon, otelin konumu, personelin tutumu ve hizmet en önemli memnuniyet unsurları olarak belirtilmekteyken, gerçekleştirilen analiz sonucunda kibar ve yardımsever personel, oda olanakları, kahvaltı ve havuzların otel müşterilerinin yorumlarında en çok yer alan memnuniyet unsurları olduğu tespit edilmiştir. Bununla birlikte bu çalışma sonuçlarına göre, rezervasyonla ilgili problemler, fiyatlar, odalardaki banyo ve duş olanakları da en önemli memnuniyetsizlik unsurları olarak dikkat çekmektedir. Otel işletmelerine yönelik TripAdvisor'daki yorumlar incelenerek memnuniyet ve memnuniyetsizlik unsurlarının incelendiği diğer bir çalışma (Berezina ve diğ., 2016), otel odalarının fiziki özellikleri, odalarda sunulan imkanlar (yatak, havlu, halı, koltuklar), ekstra hizmet ve ücretlendirmeler, personelin olumsuz tutumları, uygunsuz davranışları, mesleki bilgi eksiklikleri ve yetersizlikleri, ilgisiz davranışlarının müşteriler tarafından yorumlarda ifade edilen en önemli memnuniyetsizlik unsurları olduğunu, bu unsurların aynı zamanda müşteri memnuniyetinin sağlanmasında da önemli bir rol oynadığı ortaya koymaktadır. Söz konusu çalışmada otelde çalışan personelin müşteri memnuniyeti ya da memnuniyetsizliği oluşmasında en önemli faktör olduğu vurgulanmaktadır.

\subsection{Otel İşletmelerinde Sosyal Medya Kullanımı ve Çevrimiçi Müşteri Yorumları}

Sosyal medya, çevrimiçi ortamda kişilerin içerikler oluşturmasına ve bunları diğer kişilerle paylaşmasına olanak sağlayan, Web 2.0 teknolojisi ile birlikte ortaya çıkan internet tabanlı uygulamalar olarak tanımlanmaktadır (Kaplan ve Haenlein, 2010: 61). Çevrimiçi ortamdaki herhangi bir içeriği (resim, video, yazı, vb.), çeşitli şekillerde paylaşmaya olanak sağlayan sosyal medyanın, kısa zamanda günümüzün en önemli iletişim araçlarından biri konumuna geldiği görülmektedir. İnternete erişim imkanlarındaki artış ve akıllı telefon teknolojisinin gelişimi, sosyal medyanın kişiler arasında kullanımını her geçen gün daha da artırmakta, işletmeler tarafindan da mevcut ve potansiyel müşterilere ulaşmada sosyal medya önemli bir araç olarak değerlendirilmektedir.

Sosyal medyayı, turizm endüstrisini önemli derecede etkileyen yeni bir teknoloji olarak niteleyen Leung ve diğ. (2013: 3-17), potansiyel turistlerin tatil kararlarında, turizm işletmelerinin faaliyetlerinde ve yönetiminde ağırlama ve turizm işletmelerinin sosyal medyanın etkinliğini dikkate almalarının önemli bir zorunluluk olduğunu ifade etmektedirler. Bundan dolayı günümüzde, çeşitli alanlarda faaliyet gösteren tüm işletmeler gibi turizm endüstrisindeki konaklama işletmelerinin de sosyal medyayı yoğun bir biçimde kullandıkları görülmektedir. Sosyal medyada işletmeler ya da tatil yöreleriyle ilgili paylaşılan içerikler, potansiyel turistlerin tatil yeri tercihlerini de etkileyebilmekte, bu da konaklama işletmelerinin sosyal medya mecralarında yer almalarını teşvik etmektedir. Dolayısıyla, konaklama işletmelerinin yöneticileri, sosyal medyayı kurumsal düzeyde, konaklama işletmesinin kârlarını arttırma, müşteri memnuniyeti sağlama gibi hedeflerine ulaşmada etkili bir araç olarak kullanmaktadırlar (Yılmazdoğan ve Özel, 2014: 38). 


\section{Resim 1: Turunç Premium Hotel Kurumsal Facebook Sayfası}

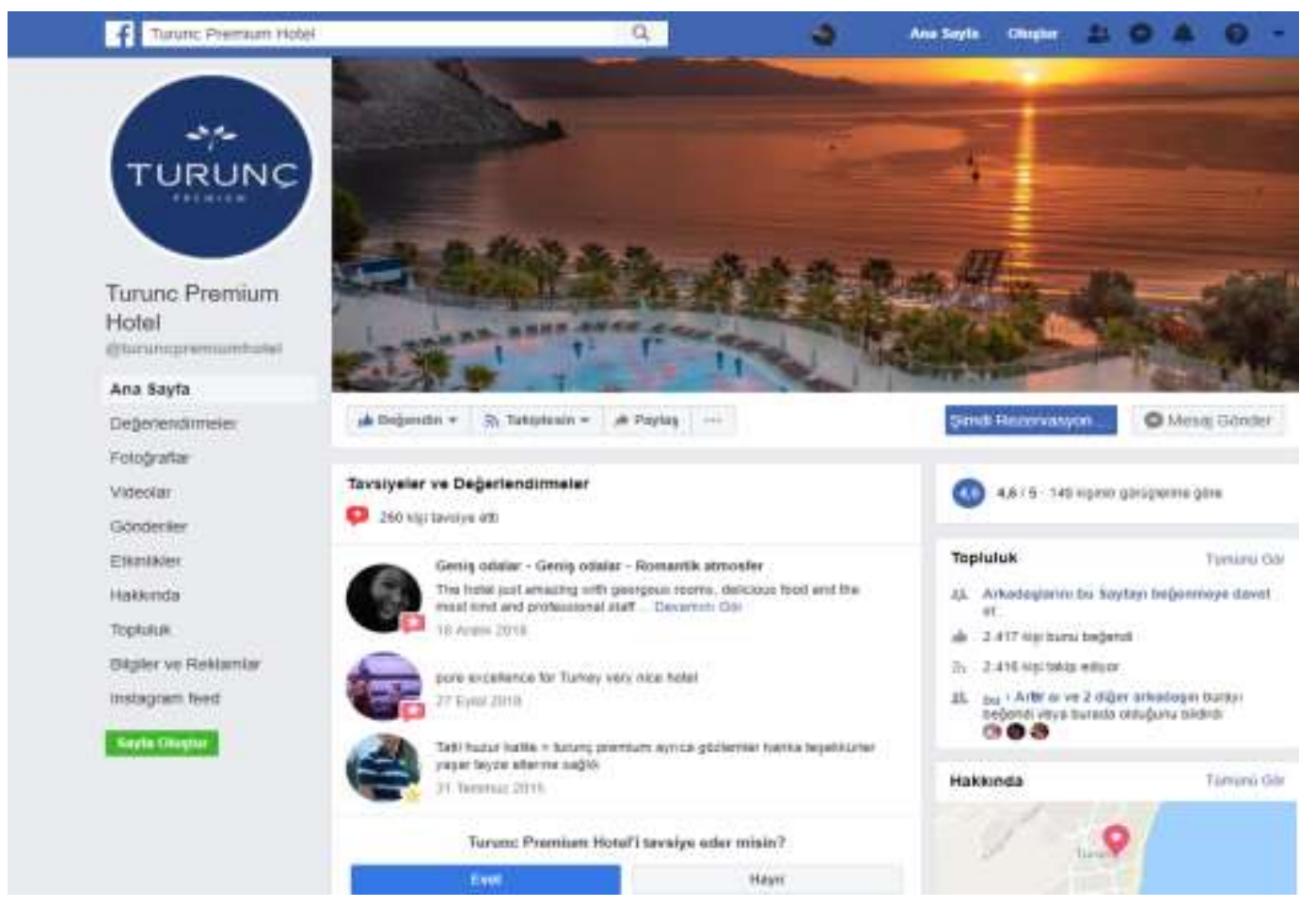

Kaynak: https://www.facebook.com/turuncpremiumhotel/

Eryılmaz ve Zengin (2014: 43), satın alma öncesi denenme şansı olmayan hizmetler hakkında kullanıcı görüşlerinin alınmasında sosyal medyayı önemli bir kaynak olarak nitelendirmekte, tüketicilere ulaşma, hizmetlerin tanıtımı, tüketicilerden yaşadıkları hizmet deneyimleriyle ilgili geribildirimler alma gibi hususlarda sosyal medyanın işletmeler için etkin bir araç olduğundan bahsetmektedirler. Yazarlar, Twitter, Bloglar, Instagram, Facebook gibi sosyal ağlarda otel işletmeleri veya diğer kişiler tarafından paylaşılan fotoğraf, bilgi, video, yorumlara ulaşılabildiğini, bunların potansiyel turistlerin tercihlerini etkileyebilecek önemli unsurlar olduğunu belirtmektedirler.

Dünya genelinde en çok kullanılan sosyal medya araçlarından biri olarak Facebook, otel işletmelerinin pazarlama, iletişim ve işletme faaliyetlerinde yoğun bir biçimde kullandığ bir mecra olarak dikkat çekmektedir. Karamehmet ve Aydın (2017) tarafından Türkiye'deki 5 yıldızlı otel işletmelerinin tamamı üzerinde gerçekleştirilen çalışmanın sonuçlarına göre, Türkiye'deki 612 adet 5 yıldızlı otel işletmesinin 441 adedinin (\%72) kendi Facebook sayfası bulunmakta ve aktif bir şekilde kullanmakta, \%28'inin ise Facebook hesapları bulunmamakta ya da aktif olarak kullanmamaktadırlar. Chan ve Guillet (2011) tarafindan otel işletmelerinin sosyal medya pazarlaması performanslarının incelendiği bir çalışmada, 23 sosyal medya aracı içerisinde Twitter $(\% 56,7)$ ve Facebook $(\% 53,7)$ 'un Hong Kong'daki otel işletmeleri tarafından en çok kullanılan sosyal medya araçları olduğu sonucuna ulaşılmıştır. Bununla birlikte çalışma bulgularında, otel işletmelerinin pazarlama faaliyetlerini en yoğun gerçekleştirdiği sosyal medya aracının Facebook olduğu, sunulan ürün ve hizmetlere yönelik indirimlerle otel konuklarının Facebook sayfasına yaptığı yorum ve şikayetlere cevap vermenin otel işletmelerinin en sık yaptığı faaliyetler olduğu ortaya konmaktadır.

Facebook gibi sosyal medya araçları kişilere, takip ettikleri işletmeler hakkında bilgi edinme, işletmenin yazılı ve görsel paylaşımlarından haberdar olma imkanı vermektedir. Ayrıca, kurumsal Facebook sayfalarında yer alan değerlendirme kısmında, müşteriler işletme hakkında yorumlarını yazabilmekte, deneyimlerini otel ve diğer takipçilerle paylaşabilmekte ve memnuniyet ya da memnuniyetsizliklerini buradan iletebilmektedirler. Bu yorumlar, potansiyel müşteriler için bir referans olabilmekte, otel işletmesini tercih etmeleri ya da etmemelerini etkileyebilmektedir. Bu bakımdan, otel işletmesi hakkında yapılan çevrimiçi müşteri yorumları dikkate alınması gereken önemli hususlardan biri olarak ifade edilebilir.

Çevrimiçi ortamda, çeşitli sosyal medya araçları üzerinden işletme hakkında yapılan tüketici yorumları, otel işletmelerinin müşteri memnuniyeti ya da memnuniyetsizliği unsurlarını anlamalarında kritik bir öneme sahiptir (Li ve diğ., 2013:785). Çevrimiçi yorumlar ile müşteriler, hizmet ya da ürünlerle ilgili deneyimlerine dayalı olarak memnuniyet düzeylerini değerlendirebilmekte, beklentilerini ifade edebilmekte, yıldız vererek puanlayabilmekte, işletme hakkında yorum yapabilmektedirler (Bilgihan ve diğ., 2018: 604-605). Müşteriler 
tarafindan yapılan yorumlar söz konusu sayfayı takip eden diğer kişiler tarafindan okunabilmekte, yorumlara katılma derecelerini belirterek yapılan bu yorumlara cevap verilebilmektedir. Otel işletmelerine yönelik sosyal medyada yapılan müşteri yorumlarının, işletmelerin sunmuş oldukları hizmetlerle ilgili performanslarını müşteri bakış açısıyla değerlendirmeleri, memnuniyet ve memnuniyetsizlik unsurlarının tespiti ve müşteri beklentilerinin anlaşılması açısından fırsatlar sunması nedeniyle oldukça önem taşıı̆ı̆ ifade edilebilir.

\section{YÖNTEM}

Sosyal medya günümüzde, müşterilerin yaşadıkları hizmet deneyimlerine ilişkin işletmeler hakkında değerlendirmeler yaparak memnuniyet ya da memnuniyetsizliklerini ifade ettikleri önemli bir iletişim arac1 konumundadır. Bu noktadan hareketle bu araştırmanın amacı, son yıllarda otel işletmelerinin aktif bir şekilde yer aldıkları sosyal medya aracı olan Facebook'taki müşteri yorumlarında müşteri memnuniyeti ve memnuniyetsizliğine ilişkin unsurları analiz ederek otel işletmeleri için çıkarımlarda bulunmaktır. Twitter, Instagram, YouTube gibi diğer sosyal medya araçları arasında Facebook'un Türkiye'de en çok kullanıcıya sahip sosyal medya aracı olması (https://www.haberturk.com/) bu araştırmada veri toplama aracı olarak tercih edilmesine neden olmuştur. Araştırmada, otel işletmelerinin kurumsal Facebook sayfalarında yapılan yorumların müşteri memnuniyeti ve memnuniyetsizliği açısından analiz edilerek bu unsurların neler olduğunun anlaşılması, otel işletmelerinin müşteri memnuniyeti sağlamaya yönelik faaliyetlerinin başarısı açısından önem taşımaktadır.

$\mathrm{Bu}$ araştırmanın evrenini, Muğla ili sınırları içerisindeki Marmaris ilçesinde faaliyet gösteren 5 yıldızlı otel işletmelerinin kurumsal Facebook sayfalarına yapılan müşteri yorumları oluşturmaktadır. 5 yıldızlı otel işletmelerinin daha profesyonel bir yönetim anlayışına sahip olmaları ve dünya genelinde en çok kullanılan sosyal medya araçlarından biri olan Facebook'ta kurumsal işletme sayfaları ile yaygın ve aktif bir şekilde yer almaları bu araştırma evreninin seçiminde etkili olmuştur.

Kültür ve Turizm Bakanlığı, Yatırım ve İşletmeler Genele Müdürlüğü resmi internet sitesinde (http://yigm.kulturturizm.gov.tr/) 02.01.2019 tarihinde yayınlanan güncel listeye göre Marmaris'te faaliyet gösteren turizm işletme belgesine sahip 5 yıldızlı otel işletmesi sayısı 17'dir. Listedeki otel işletmelerinin kurumsal Facebook sayfalarının incelenmesi sonucu, 3 adet otel işletmesinin kurumsal Facebook sayfasında müşteri değerlendirme ve yorum kısmının bulunmadığı tespit edilmiştir. Dolayısıyla, 14 adet otel işletmesinin kurumsal Facebook sayfalarında yapılan 1385 adet yorumdan, müşteri memnuniyeti/memnuniyetsizliği unsurlarını içeren, amaçlı örnekleme yöntemi ile seçilmiş 460 adet müşteri yorumu araştırmanın örneklemini oluşturmaktadır. Amaçlı örnekleme yöntemi, olgu ve olayların keşfedilmesinde ve açıklanmasında kullanılan, bir araştırmada çalışılan soruları açıklığa kavuşturacak zengin bilgi içeren durumları seçmeyi amaçlayan örnekleme yöntemidir (Tarhan, 2015: 653). Araştırma kapsamında analiz edilen müşteri yorumlarının 2016, 2017 ve 2018 yıllarına ait olması ve Türkçe ve İngilizce dillerinde olması araştırmadaki sınırlılıkları oluşturmaktadır.

Araştırma örnekleminden verilerin toplanmasında, doküman incelemesi tekniğinden yararlanılmıştır. Doküman incelemesini, araştırılması hedeflenen olay veya olgular hakkında bilgi içeren yazılı materyallerin analizini kapsayan bir teknik olarak tanımlayan Şimşek (2009: 40-43), nitel araştırmalarda sıklıkla kullanılan veri toplama tekniklerinden biri olduğuna dikkat çekmektedir. Yazara göre, doküman incelemesinde gerçekleştirilen işlemler şunlardır:

- Dokümana ulaşma,

- Dokümanların orijinalliğinin kontrol edilmesi,

- Dokümanların incelenmesi ve anlaşılması,

- Dokümanlardaki verilerin analiz edilmesi,

- Verilerin kullanılması.

Araştırmada, doküman incelemesi tekniği ile müşteri yorumlarından elde edilen verilerin çözümlemesinde içerik analizi yöntemi kullanılmıştır. Sosyal bilimler alanında sıklıkla kullanılan içerik analizi, belirli kurallara dayalı kodlamalarla kitap, mektup, tarihsel dokümanlar, gazete başlıkları ve yazıları gibi bir metnin bazı sözcüklerinin daha küçük içerik kategorileri ile özetlendiği sistematik, yinelenebilir bir teknik olarak tanımlanabilir (Sert ve diğ., 2012:353). Alanyazın taraması ve müşteri yorumlarının incelenmesi sonucu, müşteri memnuniyeti ve memnuniyetsizliği unsurları kodlanarak sınıflandırılmıştır. Verilerin analizi, kodlanması ve sınıflandırılmasında MAXQDA Analytics Pro nitel veri analiz programından yararlanılmıştır. Müşteri yorumlarının analizinden elde edilen memnuniyet ve memnuniyetsizlik unsurları ana kod ve alt kodlara ayrılarak sınıflandırılmıştır.

Araştırmada, kodlama güvenirliliğini test etmek amacıyla Cohen's Kappa analizi gerçekleştirilmiştir. Bir araştırmacının, araştırmaya başlamadan önce bir konuyu önceden tanımlanmış üç ya da daha fazla kategoriye 
ayırması ve kodlamaları buna göre yapması sıkl1kla görülen bir durumdur. Bu kategorilendirme ve kodlamanın güvenirliğini değerlendirmek amacıyla araştırmacılar, bu alanda uzman bir ya da birden fazla başka araştırmacıdan aynı konuyu bağımsız bir şekilde değerlendirmesini ve kodlamasını ister. Cohen's Kappa, nominal (kategorik) bir ölçekte, iki değerlendirici arasındaki uyum katsayısının belirlenmesinde sıklıkla kullanılan yöntemlerden biridir (Warrens, 2014: 1). Bu tekniğin basit uyum istatistiğine göre avantajı, uyumun şans ile ortaya çıkması beklenen kısmında düzeltme yapmasıdır. Dolayısıyla, değerlendiriciler arası uyumun şans eseri ortaya çıkma olasılığını da hesaba katmaktadır (Aydın Kasap ve diğ., 2017: 445).

$\mathrm{Bu}$ araştırmada, müşteri memnuniyeti ve memnuniyetsizliğine ilişkin unsurlar ayrı ayr1 kategorilendirildiğinden güvenilirliğe yönelik iki ayrı analiz gerçekleştirilmiştir. Müşteri yorumları, alanında uzman başka bir araştırmacı tarafindan bağımsız bir şekilde ayrı zamanlarda yeniden kodlanmıştır. İki araştırmacı tarafından yorumlarda memnuniyet ve memnuniyetsizliğe yönelik yapılan kodlamalar IBM SPSS Statistics 21 programına aktarılmış ve iki değerlendirici arasındaki kodlama güvenilirliği Kappa analizi ile test edilmiştir. Analiz sonuçları tablo 1'de görülmektedir.

Tablo 1: Değerlendiriciler Arası Güvenirlik (Kappa Testi)

\begin{tabular}{|l|c|c|}
\hline & Kappa Değeri & p \\
\hline Müşteri Memnuniyeti & 0.751 & 0.000 \\
\hline $\begin{array}{l}\text { Müşteri } \\
\text { Memnuniyetsizliği }\end{array}$ & 0.907 & 0.000 \\
\hline
\end{tabular}

Tablo 1 incelendiğinde, müşteri memnuniyetine yönelik kodlamalarda Kappa değerinin 0.751, memnuniyetsizliğe yönelik kodlamalarda ise bu değerin 0.907 olduğu görülmektedir. Kappa istatistiği, -1 ile +1 arasında değerler alan bir istatistik olup, bu istatistiğin 0'dan küçük olması uyumun olmadığını, 1 olması ise tam bir uyumun olduğunu belirtir (Keskin, 2004: 169). Elde edilen değerlerin yorumlanmasında Landis ve Koch (1977: 165) tarafından önerilen uyum aralıkları şu şekildedir:

Tablo 2: Kappa İstatistiği Değer Aralıkları ve Uyum Gücü

\begin{tabular}{cc}
\hline \hline Kappa İstatistiği & Uyum Gücü \\
\hline \hline$<0.00$ & Zayıf \\
$0.00-0.20$ & Önemsiz \\
$0.21-0.40$ & Vasat \\
$0.41-0.60$ & Orta \\
$0.61-0.80$ & Önemli \\
$0.81-1.00$ & Mükemmele Yakın \\
\hline
\end{tabular}

$\mathrm{Bu}$ uyum aralıkları dikkate alındığında, müşteri memnuniyetine yönelik kodlamalarda iki araştırmacı arasındaki uyumun (0.751) önemli düzeyde olduğu, memnuniyetsizliğe yönelik kodlamalarda ise bu uyumun (0.907) mükemmele yakın düzeyde gerçekleştiği görülmektedir.

\section{BULGULAR}

Otel işletmelerinin kurumsal Facebook sayfalarına yapılan müşteri yorumlarının analizi ile elde edilen verilerin cinsiyete ve müşteri pazarına göre dağılımı tablo 3'te verilmektedir. Bu verilere göre, araştırma kapsamında analiz edilen 460 adet yorumdan 232'si $(\% 50,4)$ erkek, 228'i $(\% 49,6)$ ise kadın müşterilere ait yorumlardır. Bununla birlikte, iç pazar müşterisi sayısı $250(\% 54,3)$ iken, dış pazar müşteri sayısının ise 210 $(\% 45,7)$ olduğu görülmektedir. 
Tablo 3: Müşteri Yorumlarının Cinsiyete ve Müșteri Pazarına Göre Dağılımları

\begin{tabular}{|c|c|c|c|c|}
\hline Kod Sistemi & Pazar & Diş Pazar & Iç Pazar & TOPLAM \\
\hline$\checkmark @$ Cinsiyet & & & & 0 \\
\hline$\varnothing$ Erkek & & $\bullet$ & & 232 \\
\hline$@$ Kadin & & ㅂ. & & 228 \\
\hline$\sum$ TOPLAM & 0 & 210 & 250 & 460 \\
\hline
\end{tabular}

\subsection{Müşteri Memnuniyet Unsurlarına İlişkin Bulgular}

Şekil 1'de, otel işletmelerinin kurumsal Facebook sayfalarına yapılan müşteri yorumlarının analizi sonucu bulgulardan elde edilen müşteri memnuniyeti unsurları görülmektedir. Şekilde, memnuniyete ilişkin müşteri yorumlarından elde edilen 8 ana unsur olduğu görülmektedir.

\section{Şekil 1: Müşsteri Memnuniyeti Unsurları}

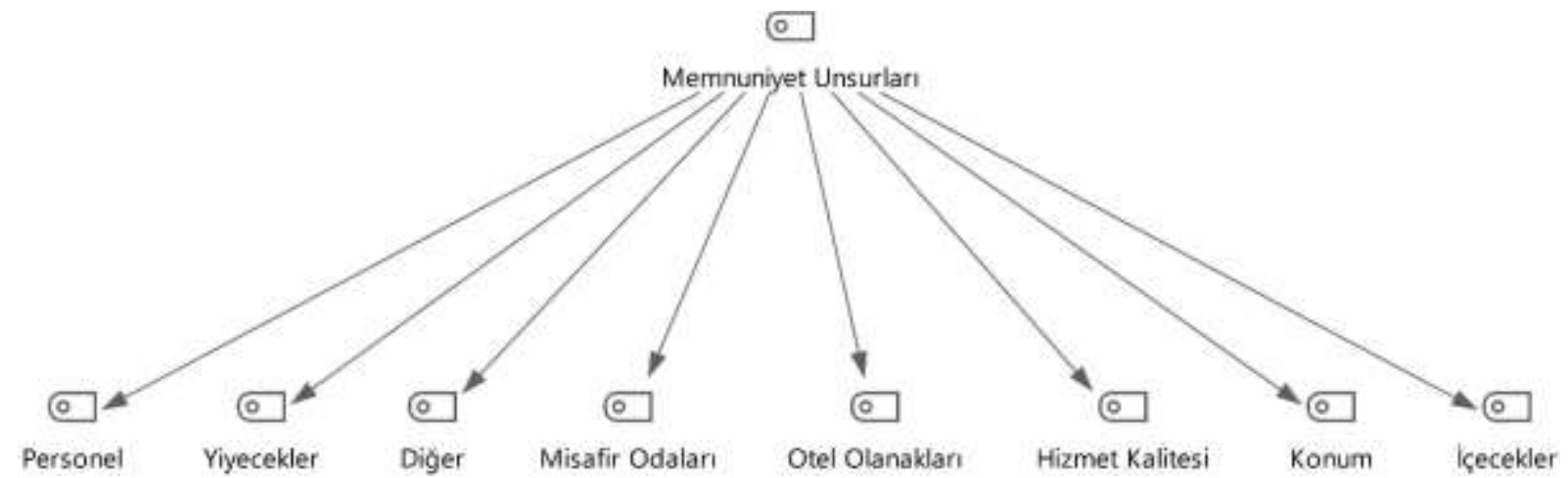

Şekil 1 incelendiğinde, müşteri yorumlarında memnuniyete ilişkin ifadelerin en sık yer aldığı ana unsurlar sırasıyla personel, yiyecekler, diğer, misafir odaları, otel olanakları, hizmet kalitesi, konum ve içecekler olarak tespit edilmiştir. Müşteri memnuniyetine ilişkin ifadelerin memnuniyet ana unsurlarında bulunma sıklı̆̆na göre oranları Grafik 1'de verilmektedir.

\section{Grafik 1: Müş̧teri Memnuniyet Unsurlarına İliș kin Oranlar}

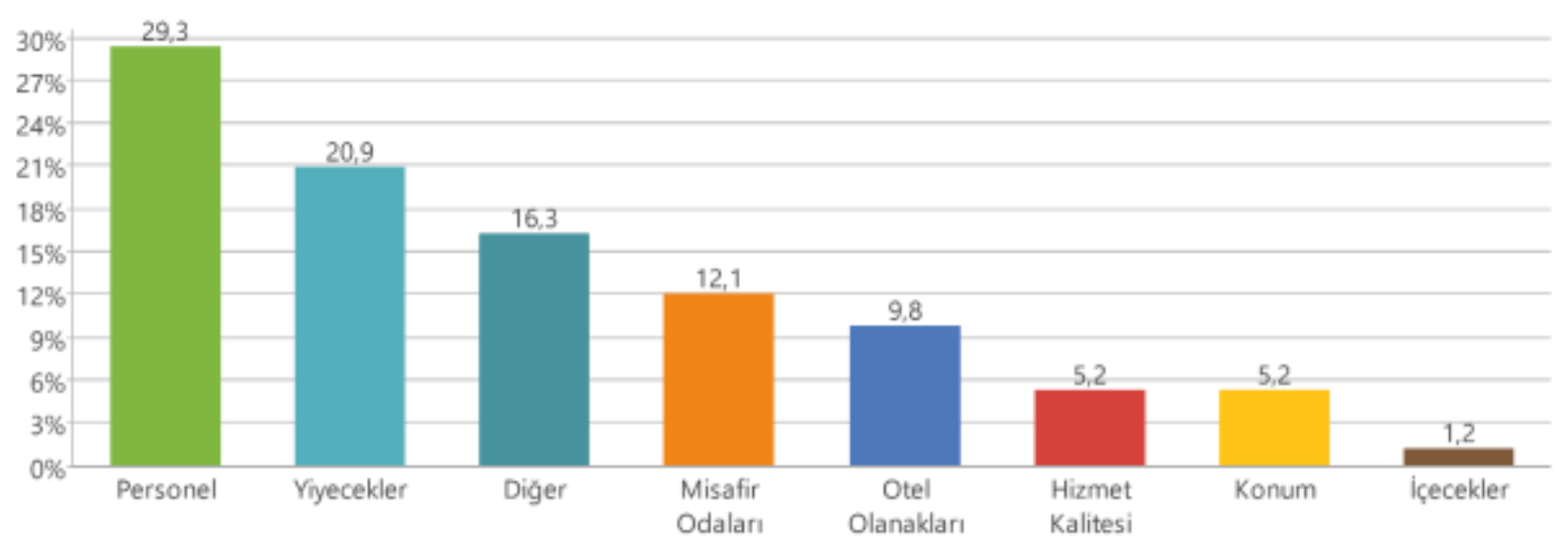


Tablo 4: Müşteri Memnuniyet Unsurlarına İlişkin Frekans ve Yüzdeler

\begin{tabular}{|c|c|c|c|c|c|}
\hline Ana Unsurlar & $\mathbf{n}$ & $\%$ & Alt Unsurlar & $\mathbf{n}$ & $\%$ \\
\hline \multirow{5}{*}{ Personel } & \multirow{5}{*}{354} & \multirow{5}{*}{29,3} & Kibar Nazik ve Saygılı Olması & 90 & 25,4 \\
\hline & & & Güleryüzlü Olması & 85 & 24,0 \\
\hline & & & İşlerini İyi Yapmaları & 79 & 22,3 \\
\hline & & & Misafirle İlgili Olmas1 & 60 & 16,9 \\
\hline & & & Yardımsever Olmas1 & 40 & 11,3 \\
\hline \multirow{3}{*}{ Yiyecekler } & \multirow{3}{*}{253} & \multirow{3}{*}{20,9} & Lezzetli Olması & 176 & 69,6 \\
\hline & & & Yemek Çeşitlerinin Yeterliliği & 50 & 19,8 \\
\hline & & & Yiyeceklerin Kaliteli Olması & 27 & 10,7 \\
\hline \multirow{5}{*}{ Diğer } & \multirow{5}{*}{197} & \multirow{5}{*}{16,3} & Genel Temizlik & 67 & 34,0 \\
\hline & & & Doğal Ortamın Çekiciliği & 56 & 28,4 \\
\hline & & & Denizin/Plajın Temizliği & 41 & 20,8 \\
\hline & & & Otel Atmosferinin Cazip Oluşu & 20 & 10,2 \\
\hline & & & Sessiz Sakin Ortam & 13 & 6,6 \\
\hline \multirow{6}{*}{ Misafir Odaları } & \multirow{6}{*}{146} & \multirow{6}{*}{12,1} & Temizliği & 55 & 37,7 \\
\hline & & & Konforu & 49 & 33,6 \\
\hline & & & Manzaras1 & 13 & 8,9 \\
\hline & & & İdeal Büyüklükte Olması & 11 & 7,5 \\
\hline & & & Yatakların Rahat Olmas1 & 10 & 6,8 \\
\hline & & & Modernliği & 8 & 5,5 \\
\hline \multirow{5}{*}{ Otel Olanakları } & \multirow{5}{*}{118} & \multirow{5}{*}{9,8} & Havuzlar & 39 & 33,1 \\
\hline & & & Animasyonlar & 39 & 33,1 \\
\hline & & & Akşam Eğlence Etkinlikleri & 17 & 14,4 \\
\hline & & & Diğer(Türk Hamamı, Çocuk Kulübü, vb.) & 12 & 10,2 \\
\hline & & & Spa Hizmetleri & 11 & 9,3 \\
\hline \multirow{2}{*}{ Hizmet Kalitesi } & \multirow{2}{*}{63} & \multirow{2}{*}{5,2} & Kaliteli Hizmet Verilmesi & 54 & 85,7 \\
\hline & & & Hizlı Hizmet Verilmesi & 9 & 14,3 \\
\hline \multirow{2}{*}{ Konum } & \multirow{2}{*}{63} & \multirow{2}{*}{5,2} & Denize Yakınlığı & 38 & 60,3 \\
\hline & & & Şehir Merkezine Yakınlığı & 25 & 39,7 \\
\hline \multirow{3}{*}{ İçecekler } & \multirow{3}{*}{14} & \multirow{3}{*}{1,2} & İçeceklerin Tadı & 12 & 85,7 \\
\hline & & & Kaliteli Olması & 1 & 7,1 \\
\hline & & & İçecek Çeşitlerinin Yeterli Olması & 1 & 7,1 \\
\hline Toplam & 1208 & 100 & & & \\
\hline
\end{tabular}

\subsubsection{Personele İlişskin Memnuniyet Unsurları}

Otel işletmelerinin Facebook sayfalarına yapılan memnuniyete ilişkin yorumlarda en sık ifade edilen $(\mathrm{n}=354)$ unsurların personelle ilgili olduğu görülmektedir. Yorumlarda personelin kibar, nazik ve saygıll olması $(n=90)$, güleryüzlü olması $(n=85)$, işlerini iyi yapmaları $(n=79)$, misafirle ilgili olmaları $(n=60)$ ve yardımsever olmaları $(n=40)$ en s1k ifade edilen personelle ilgili memnuniyet alt unsurları olarak dikkat çekmektedir.

"Çalışanlar çok güler yüzlü, çok samimi”"

"Personel muhteşem, güler yüzlü, nazik, müşteriyi memnun edebilmek için cansiperane çalışıyorlar"

"Staff were all lovely"

"The general staff are lovely"

"Tüm personelin güler yüzlü candan davranışları beni memnun etti"

"Lovely staff who became our friends"

"Staff are all smiley and so helpful"

"Staff are great helpful olly the entertainer is so funny"

"Personel çok ilgili güleryüzlü"

"Çalışanlar çok cana yakın güler yüzlü"

"Herkes bu kadar mı hassas itinalı olur özellikle güler yüzlü olmaları çok hoşuma gitti”

"Hizmet anlayışları ve personelin hem güleryüzlü olması hemde çok yardımcı olması hoşumuza gitti"

"Personel güler yüzlü saygılıydı" 
"Personel güler yüzlü ve yardımsever"

"Ben bu kadar güler yüzlü ve profesyonel personeli bir arada görmedim"

"Garsonlar son derece ilgili, nazik ve güler yüzlü"

"Everybody really helpful, all staff were lovely"

"As everyone has said so far the staff are the icing on the cake, polite and so helpful"

\subsubsection{Yiyeceklere İlişkin Memnuniyet Unsurları}

Müşteri yorumlarında memnuniyete ilişkin ifadelerin en sık tekrarlandığ $1(n=253)$ diğer bir ana unsur ise yiyecekler olarak tespit edilmiştir. Yiyeceklerle ilgili yorumlarda yiyeceklerin lezzetli olması $(n=176)$ en sık tekrar edilen ifadeler olarak görülmekteyken, yemek çeşitlerinin yeterliliği $(n=50)$ ve yiyeceklerin kaliteli olması ( $\mathrm{n}=27)$ sıklıkla tekrar edilen diğer memnuniyet ifadeleri olarak dikkat çekmektedir.

"Great choice of food, good quality of food"

"The food had plenty of choice and variety and was ok"

"Oteldeki en önemli şey yemeklerinin son derece harika olmasıydı bence. Açık büfede hiç sırada beklemek zorunda değilsiniz. Yemeklerin çeşitliliğini görünce gözünüz doyuyor yemek yiyemiyorsunuz”

"Food is very good and has a very large selection"

"Yemekler bir harika. Hem lezzetli hem nezih. Herşey kaliteli"

"Akşam yemekleri süper. Çeşit iyi, sabah yeterli, öğlen zayıf ama gene de iyi"

"Very good and fresh food selection"

"Yemekler oldukça iyi her kesime hitap ediyor"

"Yemek çeşitleri o kadar çok ki insanların kilo almama gibi bir şansı yok"

"Yemekleri çok lezzetli çeşidi bol saymakla bitmez"

"Brilliant food for everyone"

"Food buffet was on of the best I ever tasted"

"Yemek çeşidi yeterli ve lezzetli"

"Great selection of dishes, beautifully presented and tasted"

"All include food has lots of choice, fresh, hot and lots of it"

"The kitchen had offered variety of food and it was pretty good"

"Yemekler harika ve sadece göze hitap eden değil aynı zamanda mideye hitap eden güzellikte ve temizlikte ve bol çeşitli"

\subsubsection{Diğer Memnuniyet Unsurları}

Otel işletmelerinin Facebook sayfalarına yapılan müşteri yorumlarında memnuniyete ilişkin ifadelerin en sık tekrarlandığı üçüncü kategori ise diğer unsurlardır. Bu unsurlar içerisinde otelin genel temizliği (n=67), doğal ortamın çekiciliği $(n=56)$, denizin/plajın temizliği $(n=41)$, otel atmosferinin cazip oluşu $(n=20)$ ve sessiz sakin ortam $(\mathrm{n}=13)$ yer aldığı görülmektedir. Memnuniyete ilişkin diğer unsurlarla ilgili yorumlarda geçen bazı ifadeler şu şekildedir:

"Doğa ve denizin birleştiği sakin havasıyla size güzel bir tatil hazzı bırakacaktır..."

"Otelde deniz manzarasına karşı yemek yerken hoş ve dinlendirici sesiyle güzel tınılar unutulmaz bir tatil keyfi"

"We were looking for relaxing holiday \& certainly found it here"

"Hotel is always clean"

"Temiz ve temiz..."

"Ortak kullanılan yerlerin temizliği, bakımı konusunda başarılı"

"Güzel bakımlı tesis. Çok temiz"

"Otelin temizliği odaların temizlik ve düzeni muhteşem"

"Nice clean hotel"

"Temizlik konusunda dört dörtlük bir otel mis gibi kokuyor"

"Rooms are very clean so also the whole hotel"

"Great atmosphere"

"Süper bir otel personeli ve elit havası gerçekten fazlaca dikkat çekici"

"Deniz ve koy harika..."

"Amazing natüre unbeliavable place"

"Denizi, kumsalı, konumu, doğası ve ambiyansı ile yaşanılması gereken bir tatil mekanı"

"You will be amazed by natural beauty"

"Hizmeti, denizi, kumu bağımlılık yapıyor" 


\subsubsection{Misafir Odalarına İlişkin Memnuniyet Unsurları}

Müşteri memnuniyeti ile ilgili yapılan yorumlarda en sık tekrar edilen ifadelerden bir diğeri de misafir odaları ile ilgili memnuniyet unsurlarıdır. Odaların temizliği $(n=55)$ ve konforu $(n=49)$ bu kategoride en sik tekrar edilen ifadeler olarak dikkat çekmekteyken, odaların ideal büyüklükte olması $(n=11)$, yatakların rahat olması $(n=10)$ ve odaların modernliği $(n=8)$ gibi unsurlar da müşteri yorumlarında ifade edilen diğer memnuniyet unsurlarıdır.

"The room was lovely, large double bed an done single bed with a large wardrobe space"

"Yatakları muhteşem ötesi çok dinlendirici ve keyif verici"

"Tertemiz güzel oda rahat yatak ve yastıklar"

"The beds were very comfortable"

"Rooms cleaned everyday"

"Odaların temizlik ve düzeni muhteşem"

"Very clean, comfy beds"

"Odalar son derece konforlu ve temiz"

"Oda konforu ver çalışanların güler yüzü memnun ediyor"

"The rooms look very nice and modern"

"Really nice updated rooms"

"The rooms are good size with beatifull sea view"

\subsubsection{Otel Olanaklarına İlişskin Memnuniyet Unsurları}

Müşteri yorumlarında memnuniyet ifadelerinin sıklıkla tekrarlandığ 1 bir diğer ana unsur olarak otel olanakları görülmektedir. Havuzlar $(n=39)$ ve animasyonlara $(n=39)$ ilişkin ifadeler bu kategori altında en sık tekrarlanan memnuniyet ifadeleri olmakla birlikte, akşam eğlence etkinlikleri $(n=17)$, Türk hamamı, çocuk kulübü gibi diğer otel olanakları $(n=12)$ ve spa hizmetleri $(n=11)$ de memnuniyete ilişkin ifadelerin yoğunlaştığı diğer alt unsurlardır.

"Kids club was great fort he kids though"

"Otelin en güzel yanı havuzları ve hamamıdd"

"Havuzlar büyük ve temizdi gerçekten"

"I would definitely recommend the Turkish bath and massage"

"Really would recommend you g oto the spa"

"Hotel facilities are absolutely fantastic"

"Animasyonları çok güzel"

"Great entertainment team and evening programme"

"Animasyon ekibi sabah bizlerle başlayıp güne gece geç saatlere kadar enerjileri azalmadan tüm müşterileri memnun etmek adına muhteşem gösterilerle emek vermekteler"

"Su oyunları, gece animasyonlar bir harikaydı"

"Gece animasyonu hergün farklı ve çok eğlenceliydi"

\subsubsection{Hizmet Kalitesi, Otelin Konumu ve İçeceklere İlişkin Memnuniyet Unsurları}

Otel işletmelerinin Facebook sayfalarına yapılan yorumlarda otel olanaklarından sonra sırasıyla hizmet kalitesi, otelin konumu ve içecekler ana unsurlarında memnuniyete ilişkin ifadelerin sıklıkla yer aldığı tespit edilmiştir. Kaliteli hizmet verilmesi $(n=54)$ ve hızlı hizmet verilmesi $(n=9)$ hizmet kalitesine ilişkin ifadelerin bulunduğu alt unsurlar olarak görülmekteyken, otelin denize yakınlığ $(\mathrm{n}=38)$ ve şehir merkezine yakınlığ 1 $(n=25)$ konuma, içeceklerin tadı $(n=12)$, kaliteli olması $(n=1)$ ve içecek çeşitlerinin yeterli olması $(n=1)$ içeceklere ilişkin memnuniyet ifadelerinin yer aldığ 1 alt unsurlardır.

"Excellent quality of service"

"Hizmeti ile muhteşem bir otel"

"Servis hizlı"

"Konum süper. Şehrin yakınında, ama onun dışında"

"Otel konum olarak çok güzel"

"Açık ve kapalı havuzu, ayrıca denize sıfır konumunda olması güzel"

"Wine was drinkable which is a plus plus"

"Çayı ve türk kahvesi çok iyi"

"There are a great range of drinks available"

"Good quality of food" 
Müşteri memnuniyetine yönelik otel işletmelerinin Facebook sayfalarına yapılan müşteri yorumlarının analizi sonucu elde edilen bulgulara göre, yorumlarda memnuniyete ilişkin ifadelerin en sık personel ana unsuru altında olduğu görülmektedir. Bunu sırasıyla yiyecekler, diğer, misafir odaları, otel olanakları, hizmet kalitesi, konum ve içeceklerle ilgili memnuniyet ana unsurları takip etmektedir.

\subsection{Müşsteri Memnuniyetsizliği Unsurlarına İlişkin Bulgular}

Şekil 2'de, otel işletmelerinin kurumsal Facebook sayfalarına yapılan yorumlarda müşteri memnuniyetsizliğine ilişkin ifadelerin 6 ana unsur altında toplandığı görülmektedir. Müşteri memnuniyetsizliğine ilişkin ifadelerin en sık yer aldığı ana unsurun yiyecekler $(n=105)$ olduğu, bunu sirasıyla personel $(n=101)$, diğer $(n=87)$, hizmet/ekipman eksiklikleri $(n=79)$, temizlik $(n=47)$ ve içecekler $(n=23)$ ana unsurlarının takip ettiği görülmektedir.

\section{Şekil 2: Müşteri Memnuniyetsizliği Unsurları}

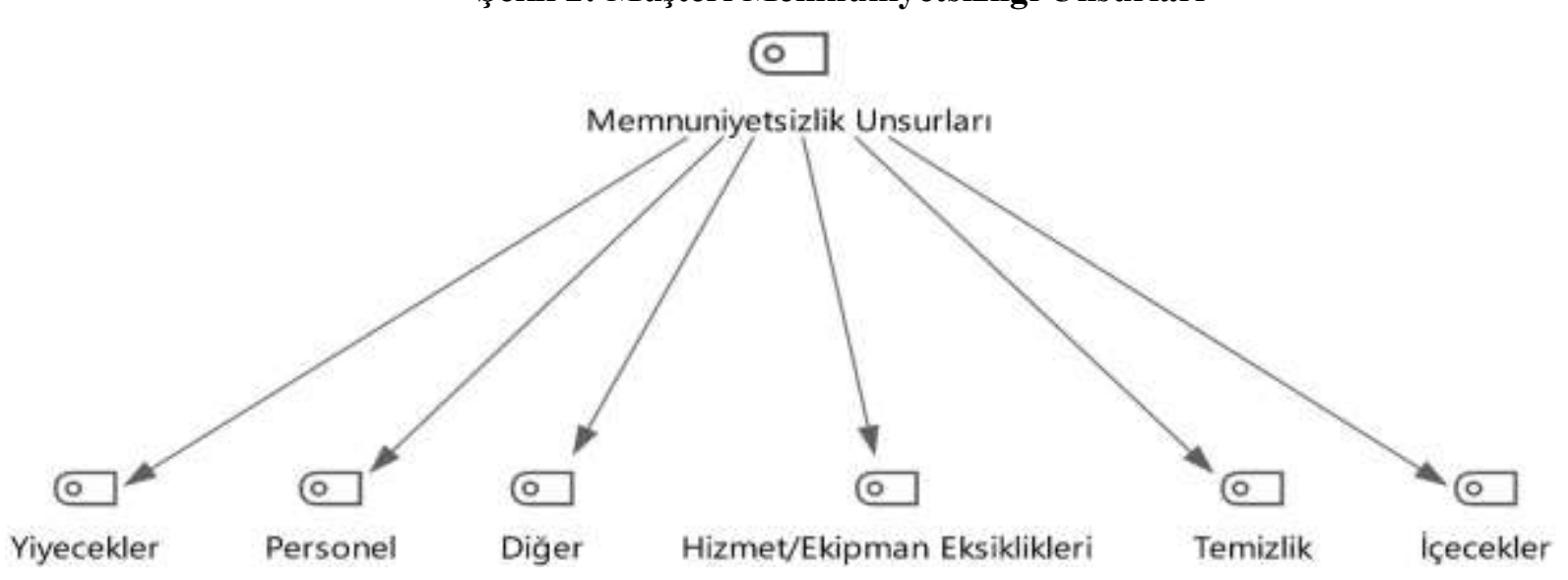

Müşteri memnuniyetsizliğine ilişkin ifadelerin bulunma sıklığına göre ana unsurların oranları grafik 2'de verilmektedir.

\section{Grafik 2: Müşteri Memnuniyetsizlik Unsurlarına İlişkin Oranlar}

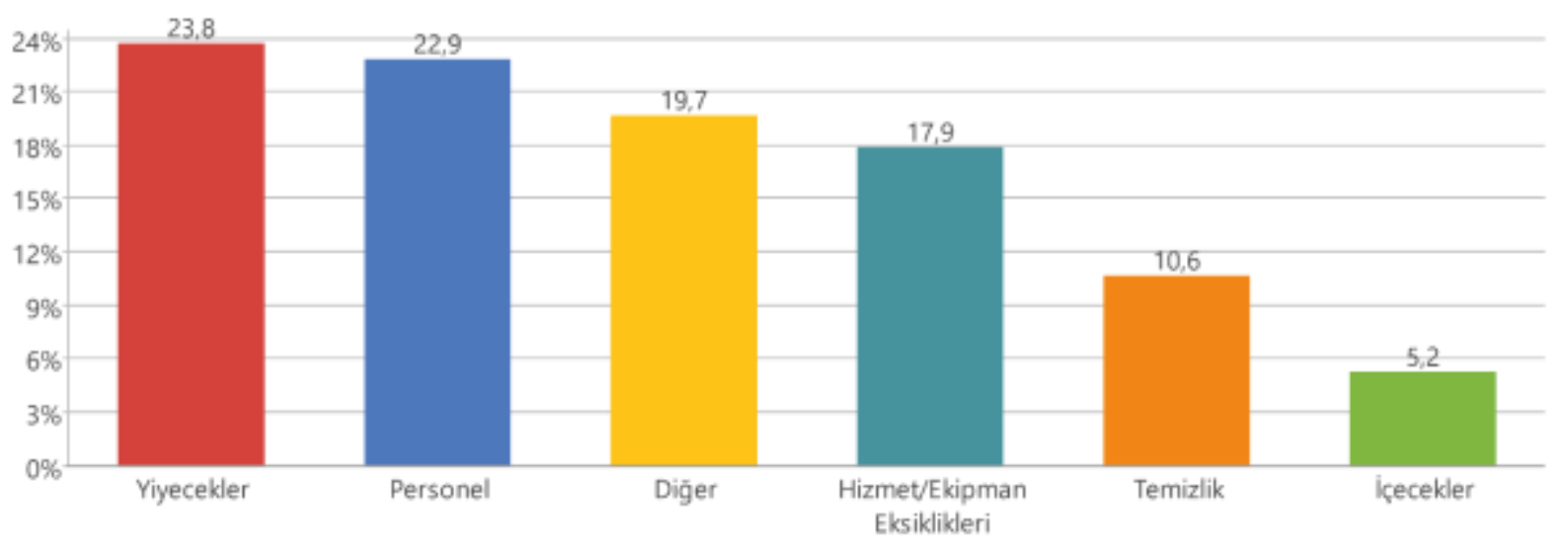


Tablo 5: Müşteri Memnuniyetsizlik Unsurlarına İlişsin Frekans ve Yüzdeler

\begin{tabular}{|c|c|c|c|c|c|}
\hline Ana Unsurlar & $\mathbf{n}$ & $\%$ & Alt Unsurlar & $\mathbf{n}$ & $\%$ \\
\hline \multirow{5}{*}{ Yiyecekler } & \multirow{5}{*}{105} & \multirow{5}{*}{23.8} & Lezzetsiz Olmas1 & 37 & 35.2 \\
\hline & & & Çeşitlerin Az Olması & 23 & 21.9 \\
\hline & & & Kalitesiz Olmas1 & 20 & 19.0 \\
\hline & & & Sürekli Aynı Yiyeceklerin Olması & 18 & 17.1 \\
\hline & & & Hijyenik Olmaması & 7 & 6.7 \\
\hline \multirow{5}{*}{ Personel } & \multirow{5}{*}{101} & \multirow{5}{*}{22.9} & İşlerini İyi Yapmaması & 35 & 34.7 \\
\hline & & & İlgisiz Olmaları & 29 & 28.7 \\
\hline & & & Kaba Davranışları & 19 & 18.8 \\
\hline & & & Güler Yüzlü Olmaması & 12 & 11.9 \\
\hline & & & Disiplinsiz Davranışlar & 6 & 5.9 \\
\hline \multirow{5}{*}{ Diğer } & \multirow{5}{*}{87} & \multirow{5}{*}{19.7} & Kötü Hizmet Kalitesi & 39 & 44.8 \\
\hline & & & Ekstra Ücretli Hizmetlerin Fazla Olmas1 & 21 & 24.1 \\
\hline & & & Otopark Yetersizliği & 11 & 12.6 \\
\hline & & & Otelin Gürültülü Olmas1 & 11 & 12.6 \\
\hline & & & Ulasım ve Güvenlik Sorunları & 5 & 5.7 \\
\hline \multirow{6}{*}{$\begin{array}{l}\text { Hizmet/Ekipman } \\
\text { Eksiklikleri }\end{array}$} & \multirow{6}{*}{79} & \multirow{6}{*}{17.9} & Aktivitelerin Azlığ 1 & 18 & 22.8 \\
\hline & & & Odalardaki Eski/Bozuk Eşyalar & 18 & 22.8 \\
\hline & & & Diğer Eksiklikler & 16 & 20.3 \\
\hline & & & Yetersiz Kablosuz Ağ Bağlantıs1 & 12 & 15.2 \\
\hline & & & Şezlong Yetersizlikleri & 11 & 13.9 \\
\hline & & & Havuzların Yetersizliği & 4 & 5.1 \\
\hline \multirow{3}{*}{ Temizlik } & \multirow{3}{*}{47} & \multirow{3}{*}{10.6} & Odaların Temiz Olmaması & 30 & 63.8 \\
\hline & & & Genel Temizliğin Kötü Olması & 13 & 27.7 \\
\hline & & & Denizin/Plajın Kirli Olması & 4 & 8.5 \\
\hline \multirow{3}{*}{ İçecekler } & \multirow{3}{*}{23} & \multirow{3}{*}{5.2} & Tatlarının Kötü Olması & 9 & 39.1 \\
\hline & & & Kalitesiz Olması & 8 & 34.8 \\
\hline & & & Çeşitlerin Az Olması & 6 & 26.1 \\
\hline Toplam & 442 & 100 & & & \\
\hline
\end{tabular}

\subsubsection{Yiyeceklere İliş̧kin Memnuniyetsizlik Unsurları}

Tablo 5 incelendiğinde, otel işletmelerinin Facebook sayfalarına yapılan müşteri yorumlarında memnuniyetsizliğe ilişkin ifadelerin en çok yoğunlaştığ 1 ana unsurun yiyecekler $(\mathrm{n}=105)$ olduğu görülmektedir. Yiyeceklerin lezzetsiz olması $(n=37)$, çeşitlerin az olması $(n=23)$, kalitesiz olması $(n=20)$, sürekli aynı yiyeceklerin olması $(\mathrm{n}=18)$ ve hijyenik olmaması $(\mathrm{n}=7)$ yiyeceklerle ilgili yorumlarda ifade edilen memnuniyetsizlik alt unsurlarıdır.

"Pis tabak ve bardaklar..."

"Old food that stuck to it not heigenic"

"Yiyecekler içecekler kalitesiz hep aynı, bazı yerlerde çok pis koku var"

"Yemek çeşidi az"

"Yemekler yemin ediyorum hindiden başka bir şey yok"

"Yemeklerin vasat olması, ara öğünlerin kalitesizliği"

"Hergün aynı yemekler çıkıyor ve taze yemek yok"

"Beş yıldızlı bir otele göre yemekler çok vasat hazır ürünler kullanılıyor kahvaltı kötü kullanılan zeytin peynir kalitesiz"

"Yemekler gerçekten kötü"

"Yemekler lezzetsiz çeşit az"

\subsubsection{Personele İlişsin Memnuniyetsizlik Unsurları}

Müşteri yorumlarında yiyeceklerden sonra en çok ifade edilen memnuniyetsizlik ana unsurunun ise personel $(\mathrm{n}=101)$ olduğu görülmektedir. $\mathrm{Bu}$ ana unsur altında bulunan personelin işlerini iyi yapmamas1 $(n=35)$, ilgisiz olmaları $(n=29)$, kaba davranışları $(n=19)$, güler yüzlü olmaması $(n=12)$ ve disiplinsiz davranışları $(\mathrm{n}=12)$ memnuniyetsizlik alt unsurlarıdır. 
“Tecrübesiz elemanların çalıştığı ultra alakasız bir tesis"

"Hizmet sifirın altında kimse sizinle ilgilenmiyor"

"Staff is not all helpful. Most of the staff looks very angry"

"The staff are rude and ignorant"

"Bir garson resmen yanımızda küfür etti"

"Resepsiyondaki bey çok ahlaksız saygısız insanlarla nasıl iletişim kurulacağını bilmiyor"

"Çalışanlar çok tecrübesiz ve acemi...yani çok yol katetmesi lazım..."

"Animasyon ekibi yetersiz ve amatörce çocuklara çikolota partisi var diye anans yapıyorlar"

"Personeli yıldırmışlar yüzleri ne yazıkki gülmüyor"

"Serviste bulunan elemanların yüzü gülmüyor"

\subsubsection{Diğer Memnuniyetsizlik Unsurları}

Müşteri memnuniyetsizliğine ilişkin yorumlarda en sık ifade edilen üçüncü ana unsur olarak diğer unsurlar $(n=87)$ görülmektedir. Kötü hizmet kalitesi $(n=39)$, esktra ücretli hizmetlerin fazla olması $(n=21)$, otopark yetersizliği $(n=11)$, otelin gürültülü olması $(n=11)$, ulaşım ve güvenlik sorunları $(n=5)$ diğer ana unsuru altındaki memnuniyetsizliğe ilişkin alt unsurlar olarak dikkat çekmektedir.

"Güvenliğin olmamasından rahatsız olduk"

"Havaalanında ulaşım çok kötü, yollar çok bozuk"

"Enerji içeceği bile ekstra nasıl ultra herşey dahil bu anlamadım"

"It's not totally all inclusive as there are lots of extras i.e., ice cream at pool area, that you have to pay for"

"Çok acemice verilen hizmetler"

"Very bad service quality"

"Dondurmayı kağıt çay bardağında vermesi, saat 2'yi geçmesine rağmen otele giriş yaptırmaması, oteli ultra herşey kötü hale getiriyor"

"Otopark sorunu var vale hizmeti yok"

"Otopark dolu yer yok"

"Noisy untill midnight, very annoying if your wşth kids"

"The music was blaring from the pool at 9 am right through to $5 / 6$ at night"

\subsubsection{Hizmet/Ekipman Eksikliklerine İlişkin Memnuniyetsizlik Unsurları}

Müşteri yorumlarında ifade edilen memnuniyetsizlik ana unsurlarından dördüncüsü olarak hizmet/ekipman eksiklikleri ( $\mathrm{n}=79)$ görülmektedir. Bu ana unsur altındaki alt unsurlar ise aktivitelerin azlığ $1(\mathrm{n}=18)$, odalardaki eski/bozuk eşyalar $(n=18)$, diğer eksiklikler $(n=16)$, yetersiz kablosuz ağ bağlantısı $(n=12)$, şezlong yetersizlikleri $(\mathrm{n}=11)$ ve havuzların yetersizliğidir $(\mathrm{n}=4)$.

"Çocukları eğlendirecek hiçbir faaliyet göremedik"

"Aktivte yok gezecek bir yer yok"

"Entertainment in evening was practically non exist.."

"Ara öğünde yiyecek bir şey almaya gittiğiniz tabak kalmaması"

"Küçük bir restoranda yer kapma savaşı"

"Otelin acil olarak bakıma eşyalarının değiştirilmesine ihtiyaç var"

"Yataklar çekyattan bozma"

"Air con works when it wants to"

"Aircon that was working very poor"

"Odalardaki fön makinaları yetersiz, bozuk"

"Şezlonglar yetersiz. Hergün boşşezlong bulmak için yarışıyorsunuz"

"Sürekli çekmeyen wi-fi var"

"Wi-fi only available in loby and pool area"

"Havuz kalabalık olduğu için yetersiz kalıyor..."

\subsubsection{Temizliğe İlişkin Memnuniyetsizlik Unsurları}

Müşteri yorumlarında en sık ifade edilen beşinci memnuniyetsizlik ana unsuru temizlik $(n=47)$ olarak dikkat çekmektedir. Bu ana unsur altında odaların temiz olmaması $(n=30)$, otelin genel temizliğinin kötü olması $(n=13)$ ve denizin/plajın krili olması $(n=4)$ memnunieytsizlikle ilgili alt unsurlardır.

"Temzilik desen o da yok girdiğim hiçbir tuvalette klozet örtüsü yoktu"

"Otele geldik iki gün sonra kızım alerji oldu onun ardından eşimin parmağı mikrop kapıp şişti daha neler neler..."

Selçuk Üniversitesi Sosyal Bilimler Meslek Yüksekokulu Dergisi, Yıl: 2019 Cilt: 22 Sayı:2 
"There's completly no chance to have a moment to relax in silence or to swim in a clean sea without risk of being killed by a motor boat or poisoned by gasoline"

"Housekkeping bölümü çok yetersiz. Balkonlardaki sehpalar bile silinmiyor kir içinde"

"Oda temizliği sıfır"

"Odalar iğrenç ve çok pis"

"The room was smelling terrible"

"4 gece kaldım çarşaf ve yastık kı1ıfları hiç değişmedi ve odada temizlik yapılmadı"

\subsection{6.İ̧ceceklere İlişkin Memnuniyetsizlik Unsurları}

Otel işletmelerinin Facebook sayfalarına yapılan müşteri yorumlarında en az sıklıkta $(n=23)$ ifade edilen son memnuniyetsizlik ana unsuru ise içeceklerdir. İçeceklerin tatlarının kötü olması ( $\mathrm{n}=9)$, kalitesiz olması $(n=8)$ ve çeşitlerin az olması $(n=6)$ bu ana unsur altındaki alt memniyetsizlik unsurları olarak görülmektedir.

"İçeceklerin çayın dahi bayat olduğu bir yer"

"İçecekler iğrenç, tatları berbat"

"Alkol olarak hiç duyulmadık markaların kullanılması"

"İsmi belirsiz kalitesiz içkileri, taze sıkılmış portakal suyuna bile damacanayla oralet karıştırılması"

"The drinks were just as bad all the fizzy drinks.."

"Selection of all inclusive drinks poor"

Yukarıdaki bulgulara göre, otel işletmelerinin Facebook sayfalarına yapılan müşteri yorumlarında, memnuniyete ilişkin ana unsurların 8 , memnuniyetsizliğe ilişkin ana unsurların ise 6 başlık altında toplandığ görülmektedir. Hem müşteri memnuniyeti hem de müşteri memnuniyetsizliğine ilişkin yorumlarda personel ve yiyecekler ana unsurlarının yorumlarda en sık ifade edilen unsurlar olduğu dikkat çekmektedir.

\section{Şekil 3: Müssteri Memnuniyeti ve Memnuniyetsizliği Unsurları}

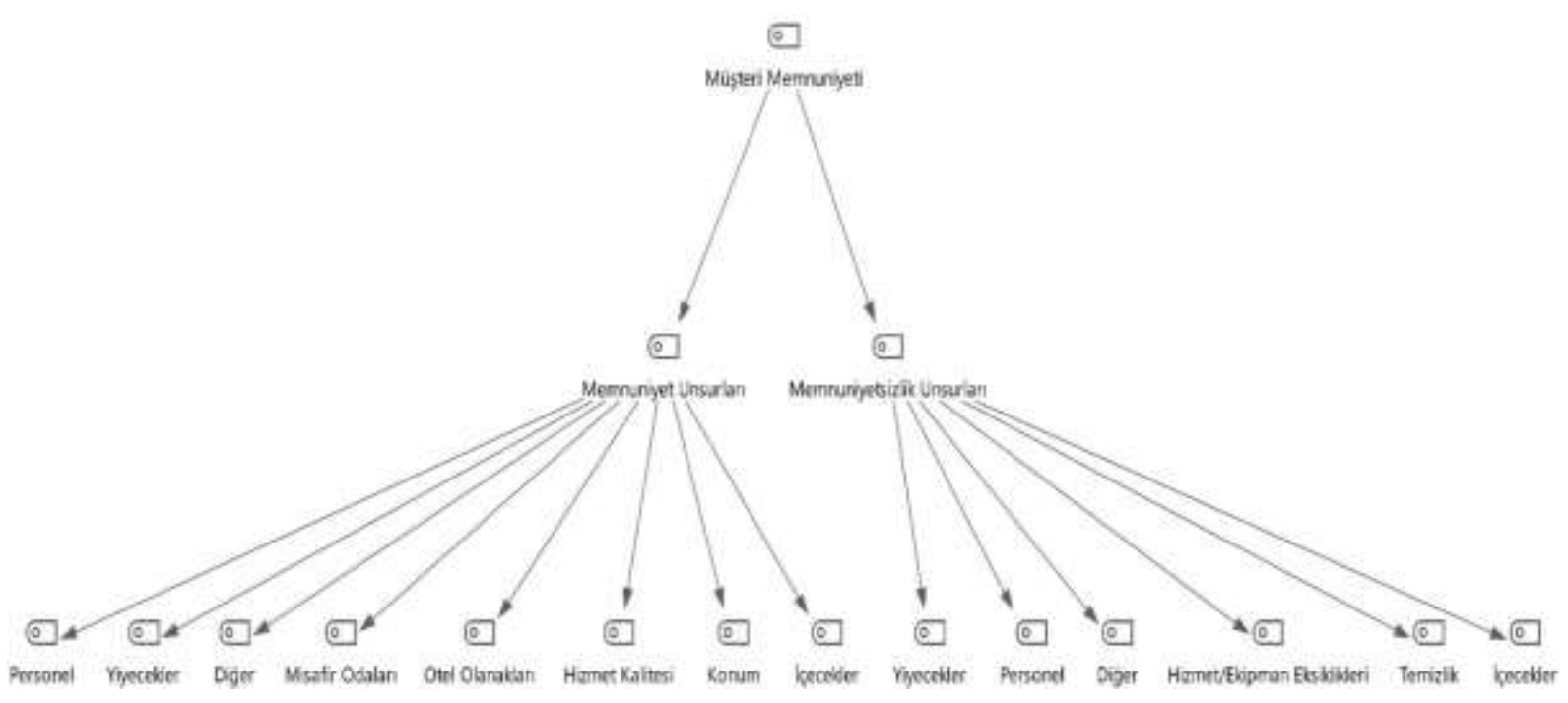

\section{TARTIŞMA VE SONUÇ}

Müşteri memnuniyeti/memnuniyetsizliği, müşterilerin beklentileri ve aldıkları hizmet performansı ile ilgili bir unsurdur. Beklentilerin karşılanması memnuniyeti sağlarken, karşılanmaması memnuniyetsizliğe neden olabilmektedir. Turizm endüstrisi içerisinde önemli bir yer sahibi olan otel işletmeleri, işletme faaliyetlerinin başarısı, devamlılığı ve rekabet avantajı elde edebilmek için müşteri memnuniyeti ve memnuniyetsizliğine neden olan unsurları analiz etmeli ve iyi anlamalıdırlar. Sosyal medya günümüzde, hem kişiler hem işletmeler tarafından yaygın bir şekilde kullanılmakta, önemli bir iletişim aracı olarak işlev görmektedir. Müşteriler, yaşadıkları hizmet deneyimleriyle ilgili memnuniyet ve memnuniyetsizliklerini işletmelerin kurumsal sosyal medya sayfalarında yorum yaparak diğer kişiler ve işletmelerle paylaşmaktadırlar. Bu sebeple, işletmelerin kurumsal sosyal medya sayfalarına yapılan müşteri yorumlarının analizi, memnuniyet ve memnuniyetsizlik unsurlarının anlaşılmasında etkili bir yöntem olarak değerlendirilmekte ve kullanılmaktadır.

Otel işletmelerinin kurumsal Facebook sayfalarına yapılan müşteri yorumların analiz edilerek müşteri memnuniyeti ve memnuniyetsizliğine ilişkin unsurları tespit etmenin amaçlandığı bu araştırmada, Marmaris'te bulunan 5 yıldızlı otel işletmelerinin kurumsal Facebook sayfalarına yapılan müşteri yorumları analize tabi 
tutulmuştur. Yorumların analizi sonucunda müşteri memnuniyeti ve memnuieytsizliği unsurları tespit edilerek ana unsurlar ve alt unsurlara göre elde edilen veriler sınıflandırılmıştır.

Müşteri memnuniyetine ilişkin yorumların analizi sonucunda personel, yiyecekler, diğer, misafir odaları, otel olanakları, hizmet kalitesi, konum ve içeceklerin otel işletmelerindeki ana memnuniyet unsurları olduğu görülmektedir. Müşteri yorumlarında en çok ifade edilen memnuniyet ana unsuru personeldir. Bu ana unsur altında personelin konuklara karşı kibar nazik ve saygılı olmaları, güler yüzlü olmaları ve işlerini iyi yapmaları en dikkat çekici memnuniyet alt unsurlarıdır. Müşteri memnuiyetine yönelik yapılan diğer çalışmaların sonuçları incelendiğinde (Özer ve Günaydın, 2010; Torres ve diğ., 2014; Cengiz Mutlubaş ve Soybal1, 2017) personel nezaketi, ilgisi, işlerini iyi yapmaları, güler yüzlü olmalarının otel işletmelerinde müşteri memnuniyeti açısından önemli unsurlar olduğu görülmekte ve bu araştırmanın sonuçları ile tutarlılık göstermektedir. Bu sebeple, otel işletmelerinde gelen konuklarla iletişim halindeki ön saha personelinin teknik bilgi ve becerilerinin yanında, güler yüzlü olmaları, konuğa karşı yardımsever, ilgili ve nazik olma özellikleri müşteri memnuniyeti açısından son derece önemli faktörlerdir.

$\mathrm{Bu}$ araştırma bulgularına göre, müş̧eri memnuniyetine yönelik yorumlarda en sık ifade edilen ikinci en önemli ana unsur ise yiyeceklerdir. Bu ana unsur altında yiyeceklerin lezzetli olması memnuniyete ilişkin en önemli alt unsurken, yemek çeşitlerinin yeterliliği ve yiyeceklerin kaliteli olması da müşteri yorumlarında sıklıkla ifade edilen yiyeceklerle ilgili alt memnuniyet unsurlarıdır. Bu sonuçlar, otel işletmelerinde müşteri memnunieytinde kibar, nazik ve yardımsever çalışanların yanısıra restoran ve yiyeceklerin de önemli faktörler olduğunu ortaya koyan Cherapanukorn ve Charoenkwan (2017)'ın çalışmasının sonuçları ile tutarlılık göstermektedir. Dolayısıyla, otel işletmelerinde sunulan yiyeceklerin lezzeti, çeşitliliği ve kalitesi otel işletmelerinde önemli müşteri memnuniyeti unsurları olarak ortaya çıkmaktadır. Otel işletmelerinin yöneticileri, konuk memnuniyetini sağlamak ve artırmak için bu unsurlar üzerinde yoğunlaşmalıdırlar.

Müşteri memnuniyetinde üçüncü sıradaki önemli ana unsurun, otel işletmelerinin genel temizliği, doğal ortamının çekiciliği, denizinin/plajının temizliği gibi alt unsurların oluşturduğu diğer ana unsuru olduğu araştırma sonuçlarında görülmektedir. Otel işletmelerinde ortak kullanım alanlarının temizliği, bulunduğu doğal ortamın ve otel atmosferinin çekiciliği ve cazibesi, denizinin plajının temizliği gibi ifadeler otel işletmelerinde müşteri memnuniyetinin sağlanmasında önem taşıyan diğer anahtar unsurlar olarak müşteri yorumlarında dikkat çekmektedir. Otel işletmesindeki lobi, restoran ve tesisin genel temizliğiyle birlikte, atmosferi, ambiyansı, otelin bulunduğu doğal ortamın, denizin/plajın temizliği ve çekiciliği gibi hususlar müşteri memnuniyeti açısından üzerinde önemle durulması gereken unsurlar olarak görülmektedir. Otel işletmeleri, müşteri memnuniyetini sağlamak adına bu unsurlara önem vermeli, bulundukları çevreyi, denizi, plajı temiz tutmalı ve doğal ortamı korumalıdırlar.

Otel işletmelerinde müşteri memnuniyetine ilişkin yorumların analizi sonucunda, memnuniyete yönelik diğer önemli ana unsurun da misafir odaları olduğu tespit edilmiştir. Misafir odalarının temizliği ve konforu burada en önemli alt unsurlar olarak dikkat çekmekteyken, odaların manzarası, büyüklüğü, modernliği ve yatakların rahat oluşu yorumlarda ifade edilen memnuniyete ilişkin diğer alt unsurlardır. Bu sonuçlara benzer şekilde, Olcay ve Sürme (2014: 847) tarafından, otel işletmelerinde müşteri şikayet unsurlarını belirlemeye yönelik gerçekleştirilen çalışmada, oda konforu ve temizlik ana unsuru altında odanın fiziki yapısı, temizlik ve hijyeni, çarşaf, kılıf ve nevresimlerin temizliği, manzarası ve konumu, dekoru, yatağın rahatlı̆̆ gibi unsurların otel işletmelerinde müşteriler tarafından kabul gören memnuniyet unsurları olduğu ortaya konmuştur. Bundan dolayı, otel işletmelerinde misafir odalarıyla ilgili söz konusu özellikleri müşteri memnuniyeti açısından önemili bir unsur olarak değerlendirmek mümkündür.

Müşteri memniyet unsurlarına ilişkin gerçekleştirilen analiz sonucu elde edilen bulgularda, misafir odalarından sonra müşteri yorumlarda en sık ifade edilen diğer bir ana unsur ise otel olanaklarıdır. Burada, havuzların büyük ve temiz oluşu, animasyonların çeşitliliği ve eğlendirici olması, animasyon ekibinin performansı en önemli memnuniyet alt unsurları olarak müşteri yorumlarında ifade edilmektedir. Bunlarla birlikte, akşam gerçekleştirilen eğlence etkinlikleri ve spa hizmetleri, çocuk kulübü, Türk hamamı gibi otel olanakları otel işletmelerinde memnuniyete ilişkin diğer alt unsurlar olarak görülmektedir. Animasyonlar, gündüz ve gece eğlence etkinlikleri, spa hizmetleri, çocuklar için sunulan eğlence ve diğer olanakların otel işletmelerinde müssteri memnuniyetini olumlu yönde etkilediği, otel işletmesini tekrar ziyaret ve tavsiye etmeyi teşvik ettiği önceki araştırmalarda (Costa ve diğ., 2004; Demir ve Şen Demir, 2015; Lo ve diğ., 2015; Albayrak ve diğ., 2017) ortaya konulmaktadır. Otel olanaklarının geliştirilmesi, aktivite ve eğlence etkinliklerinin artırılması, müşteri memnuniyeti açısından önemli unsurlar olarak düşünülmeli, otel işletmesi yöneticileri tarafından gereken hassasiyet gösterilmelidir.

Hizmet kalitesi ana unsuru altında otel işletmelerinde sunulan hizmetlerin kaliteli ve hızlı olması müşteri yorumlarında ifade edilen memnuniyet unsurlardır. Otele giriş işlemlerinde, restoranda sunulan servisin hızı 
ve kalitesinin müşteri memnuniyetini olumlu yönde etkilediği görülmektedir. Bu bulgu, hizmet kalitesinin müşteri memnuniyeti üzerinde olumlu yönde etkili olduğu sonucuna ulaşılan ilgili alanyazındaki (Suki, 2014; Şirin ve Aksu, 2016; Bucak ve Özarslan, 2016; Luo ve Qu, 2016) benzer araştırmaların sonuçlarıyla tutarlılık göstermektedir. Araştırma kapsamındaki otel işletmelerinin bir sahil yerleşim biriminde bulunması, konum olarak denize olan yakınlığın da önemli bir memnuniyet unsuru olarak ortaya çıkmasına neden olduğu ifade edilebilir. Ayrıca, otel işletmelerinde sunulan içeceklerin tadı, yorumlarda ifade edilen diğer bir memnuniyet unsuru olarak yer almaktadır. Müşteri memnuniyeti açısından bu unsurlara önem verilmesinin otel işletmeleri için fayda sağlayacağını belirtmek mümkündür.

Araştırma kapsamında otel işletmelerinin Facebook sayfalarına yapılan müşteri yorumlarında analiz edilen diğer bir konu da müşteri memnuniyetsizlik unsurlarıdır. Müşterilerin hizmet beklentilerini karşılamayan, zamanında yapılmayan hizmetler, hizmet ekipmanlarıyla ilgili sorunlar ya da meydana gelen hizmet hataları memnuniyetsizliğe neden olmaktadır. Otel işletmelerinde memnuniyetsizliğe ilişkin müşteri yorumlarının analizi sonucu elde edilen bulgulara göre, müşteri memnuniyetsizliğini meydana getiren 6 ana unsurun olduğu görülmektedir. Memnuniyetsizlik ana unsurlarından ilki yiyeceklerle ilgiliyken personel, diğer, hizmet/ekipman eksiklikleri, temizlik ve içecekler diğer ana unsurlardır.

Otel işletmelerinde müşteri memnuniyetsizliğine ilişkin yorumlarda en sık ifade edilen ana unsurun yiyecekler olduğu araştırma sonucunda ortaya konmaktadır. Bu sonuç, otel işletmelerine yönelik çevrimiçi müşteri şikayetlerinin incelendiği ve yiyecek-içecek hizmetleriyle ilgili şikayetlerin en çok ifade edilen temel şikayet unsuru olduğu sonucuna ulaşan Çulha ve diğ. (2009) tarafından yapılan araştırmanın sonuçlarıyla benzerlik göstermektedir. Burada, yiyeceklerin lezzetsiz ve kalitesiz olması, çeşitlerin az olması, sürekli aynı yiyeceklerin olması ve hijyenik olmaması yiyeceklere ilişkin memnuniyetsizlik alt unsurları olarak tespit edilmiştir. Restoranda kullanılan tabak, bardak, masa örtüsü ve benzerinin kirli olması, yemeklerde kullanılan malzemelerin kalitesiz ve bayat olması, açık büfe restoranlarda yemek çeşitlerinin az olması gibi unsurların otel işletmelerinde müşteri memnuniyetsizliğine neden olduğu görülmektedir. İlgili alanyazın incelendiğinde de (Olcay ve Sürme, 2014; Alrawadieh ve Demirkol, 2015; Demirci ve diğ., 2015) otel işletmelerinde yiyecekiçeceklerle ilgili benzer şikayet unsurlarının müşteri memnuniyetsizliğinde önemli rol oynayan faktörler olduğu dikkat çekmektedir.

Otel işletmelerinde yiyeceklerden sonra müşteri yorumlarında en sık ifade edilen memnuniyetsizlik ana unsurunun personel olduğu tespit edilmiştir. Personelin işlerini iyi yapmamaları ve ilgisiz olmaları en sık ifade edilen alt unsurlar olmakla birlikte, kaba ve disiplinsiz davranışları, güler yüzlü olmamaları ise diğer önemli memnuniyetsizlik unsurları olarak araştırma sonuçlarında ortaya çıkmaktadır. Otel işletmelerinde personelin konuklara karşı kibar, nazik, ilgili olması ve işlerini profesyonelce yerine getirmelerinin müşteri memnuniyetinde önemli bir rol oynadığı ilgili alanyazında daha önce yapılan çalışmalar (Cengiz Mutlubaş ve Soybal1, 2017) tarafindan da desteklenen bir bulgudur. Bu sebeple, otel işletmeleri tarafindan bu unsurların üzerinde önemle durulmalı, konuklara hizmet veren personelin bu özellikleri taşımasına dikkat edilmelidir. Konuklara karşı yardımsever, kibar, nazik, ilgili ve işlerini en iyi şekilde yerine getiren personel otel işletmelerinde müşteri memnuiyetini sağlayan anahtar bir faktördür.

Müşteri memnuniyetsizliğine ilişkin diğer ana unsuru altındaki kötü hizmet kalitesi ve ekstra ücretli hizmetlerin fazla olması en önemli alt unsurlar olarak dikkat çekmekteyken, otopark yetersizliği, otelin gürültülü olması, ulaşım ve güvenlik sorunları müşteri yorumlarında memnuniyetsizliğe ilişkin ifade edilen diğer unsurlardır. Hizmet kalitesi, müşteri memnuniyetinde olduğu gibi memnuniyetsizlikte de etkili ve belirleyici bir unsur olarak bu araştırmada kendini göstermektedir. $\mathrm{Bu}$ sebeple, müşteri memnuniyeti konusunda hizmet kalitesinin önemini tekrar vurgulamanın gerekli olduğu düşünülmektedir. Otel işletmelerinde konuklara sunulan bazı hizmetlerin ekstra olarak ücretlendirilmesinin (çay, kahve, su, vb.) de memnuniyetsizlik oluşturduğu görülmektedir. Burada, otel işletmelerinin ekstra ücret karşıllı̆ı sundukları hizmetler hakkında konuklarını rezervasyon ve konaklama aşamasında açık bir şekilde bilgilendirmeleri ya da düşük maliyetli bazı ürün ve hizmetlerini ücretsiz olarak sunmaları, müşteri memnuniyetsizliğinin meydana gelmesini engelleyebilecek ve hatta memnuniyeti sağlayabilecek tedbirler olarak otel işletmeleri tarafindan değerlendirilebilir. Bununla birlikte, otopark yetersizliği, otelin gürültülü olması, ulaşım ve güvenlik sorunları ile ilgili memnuniyetsizlik unsurları da otel yöneticileri tarafından dikkatle ele alınması gereken önemli hususlardır. Bu sonuçlar, 5 yıldızlı otel işletmelerinde müşteri şikayetlerinin incelendiği ve düşük hizmet kalitesi, güvenlik hizmetleri, gürültülü ortam ve yüksek ekstra ücretlendirmeler gibi unsurların otel işletmelerinde önemli şikayet unsurları olduğunu ortaya koyan Demirci ve diğg. (2015) tarafindan gerçekleştirilen araştırma sonuçlarıyla tutarlılık göstermektedir.

Otel işletmelerinin Facebook sayfalarına yapılan müşteri yorumlarında ifade edilen diğer memnuniyetsizlik ana unsuru ise hizmet/ekipman eksiklikleridir. Otelde aktivitelerin az olması, odalardaki eski/bozuk eşyaların 
yanı sıra yetersiz kablosuz ağ bağlantısı ve şezlong yetersizlikleri en sık ifade edilen alt memnuniyetsizlik unsurları olarak görülmektedir. Burada, otel işletmeleri tarafından sunulan animasyon eğlence etkinliklerinin eksikliği, bozuk klima, fön makinası gibi misafir odalarındaki ekipmanlar memnuniyetsizlikte etkili olurken, otel müşteri kapasitesine oranla yetersiz sayıdaki şezlonglar ve kablosuz internet bağlantısına erişimin zor ya da hiç olmaması memnuniyetsizliği oluşturan diğer önemli unsurlardır. Bu araştırma sonuçlarına göre, animasyon hizmetleri, otel müşterilerinin memnuniyetini sağlamada etkiliyken, bu hizmetlerin olmayışı ya da yetersizliği de memnuniyetsizlik üzerinde etkili bir unsur olarak ortaya çıkmaktadır. Bununla birlikte, otel müşterilerinin zamanlarının önemli bir bölümünü geçirdikleri misafir odalarındaki ekipmanların eski ya da bozuk olması bir diğer önemli memnuniyetsizlik unsuru olarak otel yöneticileri tarafından dikkate alınmalıdır. Modern, kaliteli eşya ve ekipmanların misafir odalarında kullanılması, otelde sunulan hizmet ve olanakların tüm konuklar için eşit bir şekilde yetecek sayıda bulunması ve otel odaları ve genel alanlarda kablosuz ağ erişiminin sağlanması, müşteri memnuniyetini artırabilecek unsurlar olarak dikkat çekmektedir.

Müşteri yorumlarının analizi sonucu, oda ve genel alanların temiz olmaması, otel işletmesinin müşterileri tarafindan kullanılan denizin/plajın kirli olması gibi unsurlar temizlik ana unsuru altındaki memnuniyetsizlik unsurları olarak görülmektedir. Benzer konuda gerçekleştirilen önceki araştırmaların sonuçlarında, otel işletmelerinde misafir odaları ile deniz, plaj, iskele, vb. genel kullanım alanlarının temizliği, bakımı ve görünümü müşteri memnuniyetinde önemli unsurlar olarak ortaya konmaktadır (Çulha ve diğ., 2009; Cengiz Mutlubaş ve Soybalı, 2017). Bu sebeple otel işletmelerinde genel kullanım alanlarının temizliği ve bakımı ile misafir odalarının temizliğine ve hijyene özen gösterilmelidir. Diğer bir memnuniyetsizlik ana unsuru olarak içecekler, bu ana unsur altında içeceklerin tatlarının kötü olması, kalitesiz ve çeşitlerin az olması otel işletmelerinde müşteriler tarafından ifade edilen memnuniyetsizlik alt unsurları olarak araştırmada elde edilen bulgular arasındadır. Özellikle Marmaris gibi deniz turizminin ağırlıkta olduğu destinasyonlarda genellikle herşey dahil sistemi ile hizmet veren otel işletmelerinde sunulan içeceklerin düşük kalitede olması ve seçeneklerin az olması müşteri memnuniyeti açısından önemli bir sorun meydana getirebilmektedir. Yemeklerde, ara öğünlerde ve gün içinde sunulan içecek çeşitlerinin artırılması, tat ve kalitesinin belirli standartlarda olması otel işletmelerinde müşteri memnuniyeti sağlamasında önemli unsurlar olarak ifade edilebilir.

Otel işletmelerinde müşteri memnuniyetini artırmak adına hem memnuniyet hem de memnuniyetsizlik unsurlarının ayrı ayrı analiz edilmesi ve yorumlanması, bu unsurların neler olduğunun tespiti kritik bir önem taşımaktadır. Otel işletmelerinde sunulan hizmetlerle ilgili hangi unsurların memnuniyet oluşturduğu, bu unsurların ifade edilme sıklığına göre önem dereceleri, otel işletmelerinin memnuniyeti artırmaya yönelik çabalarını destekleyecek kritik bir faktördür. Benzer şekilde, otel işletmelerinde hangi unsurların memnuniyetsizlik oluşturduğu ve buna yönelik müşteri yorumlarının analizi, otel işletmesi yöneticilerine müşteri memnuniyetsizliği oluşumunu engellemeye yönelik tedbir almalarında yardımcı olacak kritik bir faktör olarak düşünülebilir. Bu araştırmada elde edilen sonuçlar, otel işletmelerinde hem müşteri memnuniyeti hem de memnuniyetsizlikte müssteri yorumlarında en sık ifade edilen ilk iki ana unsurun personel ve yiyecekler olduğunu göstermektedir. Bundan dolayı bu iki unsur, otel işletmelerinde hem müşteri memnuniyeti hem de memnuniyetsizliğin iki önemli belirleyicisi olarak nitelendirilebilir. $\mathrm{Bu}$ sebeple, otel işletmelerinde müşteri memnuniyetini sağlamaya yönelik uygulamalarda bu iki unsur üzerinde önemle durulması önerilebilir. Bunlarla birlikte, bu araştırmada tespit edilen memnuniyet ve memnuniyetsizliğe yönelik diğer unsurlar da dikkate alınmalı, müşteri memnuniyeti artırılmalıdır.

Otel işletmelerinde müşteri memnuniyetine yönelik çalışmalarda, sosyal medyadaki müşteri yorumlarının analizi yaygın olarak kullanılan bir yöntem olarak dikkat çekmekle birlikte, dünya genelinde en çok kullanılan sosyal medya araçlarından biri olan Facebook özelinde bu araştırmaların sayısı artırılabilir. Facebook üzerindeki yıldızlı değerlendirme ve yorum sistemine ek olarak getirilen tavsiye etme özelliği ve tavsiye etme nedenlerinin analizi gerçekleştirilebilir. Ayrıca, kurumsal Facebook sayfasında değerlendirme kısmı bulunan seyahat acentası, restoranlar gibi diğer turizm işletmeleri için de benzer bir araştırma gerçekleştirilebilir. 


\section{KAYNAKÇA}

Albayrak, Tahir, Caber, Meltem, Öz, Ebru Kadriye, (2017) “Assessing Recreational Activities' Service Quality in Hotels: An Examination of Animation and Spa \& Wellness Services", Journal Of Quality Assurance In Hospitality \& Tourısm 18(2), s. 218-234.

Alrawadieh, Zaid, Demrkol, Şehnaz, (2015) “Konaklama İşletmelerinde E-Şikâyet Yönetimi: İstanbul’daki Beş Yıldılılı Oteller Üzerinde Bir Çalışma", Nişantaşı Üniversitesi Sosyal Bilimler Dergisi 3(1), s. 132-151.

Aydın Kasap, Zeliha, Kurt, Burçin, Yavuz, Yasemin, Albayrak, Muammer, Turhan, Kemal, (2017) "İki Sonuçlu Tanı Testlerinde Uygun Uyum İstatistiğinin Seçimi”, Tıp Teknolojileri Kongresi Ekim 12-14 Trabzon, s. 1-4.

Berezina, Katerina, Bilgihan, Anil, Cobanoğlu, Cihan, Okumus, Fevzi, (2016) "Understanding Satisfied and Dissatisfied Hotel Customers: Text Mining of Online Hotel Reviews", Journal of Hospitality Marketing \& Management 25, s. $1-24$.

Bilgihan, Anil, Seo, Soobin, Choi, Jihee, (2018) "Identifying Restaurant Satisfiers and Dissatisfiers: Suggestions from Online Reviews", Journal Of Hospitality Marketing \& Management 27(5), s. 601-625.

Bucak, Turgay, Özarslan, Hakan, (2016) "Otel İşletmelerinde Hizmet Kalitesi İle Misafir Memnuniyeti Arasındaki İlişki (Çanakkale İli Merkezindeki 4 ve 5 Yıldızlı Oteller Örneği)", Sosyal ve Beşeri Bilimler Araştırmaları Dergisi, 17(36), s. 1-28.

Bulut, Yetkin, (2011) "Otellerde Müşteri Memnuniyeti ve Bir Uygulama (Samsun Örneği)", Uluslararası Sosyal Araştırmalar Dergisi 4(18), s. 389-403.

Cengiz Mutlubaş, Ilgın, Soybalı, Hasan Hüseyin, (2017) "Müşteri Memnuniyetini Oluşturan Faktörlerin Müşteri Sadakatine Etkisinin Lojistik Regresyon Analizi İle İncelenmesi”, Türk Turizm Araştırmaları Dergisi 1(3), s. 115.

Chan, Nga Ling, Guillet, Bsak Denizci, (2011) "Investıgatıon of Socıal Media Marketıng: How Does the Hotel Industry in Hong Kong Perform in Marketıng on Social Media Websites?”, Journal of Travel \& Tourism Marketing 28, s. 345-368.

Cherapanukorn, Vimolboon, Charoenkwan, Phasit, (2017) "Word Cloud of Online Hotel Reviews in Chiang Mai for Customer Satisfaction Analysis", International Conference on Digital Arts, Media and Technology March 1-4 Chiang Mai, Thailand, s. 1-6.

Cinnioğlu, Hasan, Boz, Mustafa, (2015) "Sosyal Medya Araçlarından Facebook Sitesinin Otel İşletmeleri Açısından Kullanımının İncelenmesi: Çanakkale Örneği”, Akademik Bakış Dergisi 51, s. 249-264.

Costa, George, Glinia, Eleni, Goudas, Mario, Antoniou, Panagiotis, (2004) "Recreational Services in Resort Hotels: Customer Satisfaction Aspects", Journal of Sport Tourism 9(2), s. 117-126.

Çelik, Mücahit, (2012) "Müş̧eri Memnuniyeti Ve Hizmet Kalitesi Üzerine Adıyaman Üniversitesi Yemekhanesi’nde Bir Uygulama”, Adıyaman Üniversitesi Sosyal Bilimler Enstitüsü Dergisi 5(10), s. 29-54.

Çulha, Osman, Hacıoğlu, Güngör, Kurt, Gizem, (2009) "Otel Müşterilerinin E-Şikâyetlerine Yönelik Bir İçerik Çözümlemesi”, Seyahat ve Otel İşletmeciliği Dergisi 6(4), s. 42-49.

Day, Ralp L., (1984) "Modeling Choices Among Alternative Responses to Dissatisfaction", Advances in Consumer Research 11, s. 496-499.

Demir, Mahmut, Şen Demir, Şirvan, (2015) "Otel Animasyon Hizmetlerinin Yöneticiler ve Turistlerin Bakış Açısıyla Değerlendirilmesi”, International Journal of Social Sciences and Education Research 1(1), s. 35-48.

Demirci, Barış, Bayraktaroğlu, Engin, Seçilmiş, Cihan, (2015) "Evaluation of Consumer Complaints in Five-Star Hotels: The Case of Eskisehir", Turizm Akademik Dergisi 2(1), s. 15-21.

Dinçer, Mithat Zeki, Alrawadieh, Zaid, (2017) "Negative Word of Mouse in the Hotel Industry: A Content Analysis of Online Reviews on Luxury Hotels in Jordan", Journal of Hospitality Marketing \& Management 26(8), s. 785-804.

Erdem, Özkan, Yay, Özlem, (2017) "Tripadvisor'daki Müşteri Şikâyetlerinin Değerlendirilmesi: Antalya Örneği”, Journal of Tourism and Gastronomy Studies 5/4, s. 227-249.

Eryılmaz, Burak, Zengin, Burhanettin, (2014) "Sosyal Medyada Konaklama İşletmelerine Yönelik Tüketici Yaklaşımları Üzerine Bir Araştırma", İşletme Bilimi Dergisi 2(1), s. 147-167.

Facebook, "Turunç Premium Hotel", son erişim tarihi 25.04.2018, https://www.facebook.com/turuncpremiumhotel/?_tn__ $=2 \mathrm{Cd} \% 2 \mathrm{CP}-$

R\&eid=ARCJBcW67_WlgxaGMiUTaj6QJyTI_s22QNcB1jQpqqEZYs8DT6Mbtrb9LQxrBF2jnzh9BWwZXMTLLPY.

Habertürk, "Türkiye Sosyal Medya Kullanımında Kaçıncı Sırada?", son erişim tarihi 17.07.2019, https://www.haberturk.com/turkiye-sosyal-medya-kullaniminda-kacinci-sirada-2182408-ekonomi.

Kaplan, Andreas M., Haenlein, Michael, (2010) "Users of the World, Unite! The Challenges and Opportunities of Social Media", Business Horizons 53, s. 59-68.

Karamehmet, Bilge, Aydın, Gökhan, (2017) "Turizm Sektöründe Sosyal Medya Kullanım Etkinliğinin İyileştirilmesi: 5 Yıldızlı Oteller Üzerinde Bir Çalışma”, Uluslararası İktisadi ve İdari İncelemeler Dergisi, 16. UíK Özel Sayısı, s. 593-606.

Keskin, Sıddık, (2004) "2 x 2 Tablolarında Bazı Örnek Genişlikleri ve I. Tip Hata Seviyeleri ( $\alpha$ ) İçin Kappa (K) İstatistiğine Ait Ampirik Olarak Gerçekleşen Kritik Değerler”, Tarım Bilimleri Dergisi 10(2), s. 169-173. 
Kızılırmak, İsmail, Alrawadieh, Zaid, Aghayeva, Sabina, (2015) “Doğu Karadeniz Bölgesindeki Otel Misafirlerinin Seyahat E-Yorumlarına Yönelik Bir İçerik Çözümlemesi”, Gümüşhane Üniversitesi Sosyal Bilimler Elektronik Dergisi 6(14), s. 110-121.

Landis, J. Richard, Koch, Gary G., (1977) “The Measurement of Observer Agreement for Categorical Data”, Biometrics 33(1), s. 159-174.

Leung, Daniel, Law, Rob, van Hoof, Hubert, Buhalis, Dimitrios, (2013) "Social Media In Tourısm And Hospitalıty: A Literature Review", Journal of Travel \& Tourism Marketing 30, s. 3-22.

Li, Huiying, Ye, Qiang, Law, Rob, (2013) "Determinants of Customer Satisfaction in the Hotel Industry: An Application of Online Review Analysis", Asia Pacific Journal of Tourism Research 18(7), s. 784-802.

Lo, Ada, Wu, Corrine, Tsai, Henry, (2015) “The Impact of Service Quality on Positive Consumption Emotions in Resort and Hotel Spa Experiences", Journal of Hospitality Marketing \& Management 24, s. 155-179.

Luo, Zhenpeng, Qu, Hailin, (2016) “Guest-Defined Hotel Service Quality and Its Impacts on Guest Loyalty”, Journal Of Quality Assurance In Hospitality \& Tourism 17(3), s. 311-332.

Olcay, Atınç, Sürme, Metin, (2014) “Otel İşletmelerinde Müşteri Şikâyetlerini Belirlemeye Yönelik Ampirik Bir Çalışma”, Uluslararası Sosyal Araştırmalar Dergisi 7(35), s. 836-855.

Oliver, Richard L., (1993) “Cognitive, Affective, and Attribute Bases of the Satisfaction Response”, Journal of Consumer Research 20(3), s. 418-430.

Oliver, Richard L., (1999) "Whence Consumer Loyalty?”, Journal of Marketing 63, s. 33-44.

Özer, Özgür, Günaydın, Yusuf, (2010) “Otel İşletmelerinde Müşteri Memnuniyeti ve Müşteri Sadakati İlişkisi: Dört Yıldızlı Otel İşletmelerinde Bir Uygulama”, İşletme Fakültesi Dergisi 11 (2), s. 127-154.

Prasadh, R. Ragu, (2018) "Examining The Roles of Perceived Quality and Customer Satisfaction as Predictors of Customer Loyalty in the Indian E-Banking Context", Journal of Management Research 18(3), s. 176-187.

Rashed, Choudhury Abul Anam, Rifath, Jannatul, Begum, Rumena, Bhu1yea, Md. Shabbir Hossain, (2018) "Investigation of Satisfaction Level of Customers and Hidden Factors for Selected Retail Store Shopping", Review of General Management 27(1), s. 22-43.

Sert, Gülşen, Kurtoğlu, Meltem, Akıncı, Ahmet, Seferoğlu, S. Sadi, (2012) "Öğretmenlerin Teknoloji Kullanma Durumlarını İnceleyen Araştırmalara Bir Bakış: Bir İçerik Analizi Çalışması”, Akademik Bilişim’12- XIV. Akademik Bilişim Konferansı Bildirileri, 1-3 Şubat 2012, Uşak, s. 351-357.

Shah, Syed Naseeb Ullah, Jan, Shahid, Baloch, Qadar Bakhsh, (2018) "Role of Service Quality and Customer Satisfaction in Firm's Performance: Evidence from Pakistan Hotel Industry”, Pakistan Journal of Commerce and Social Sciences 12(1), s. 167-182.

Sim, Janet, Mak, Brenda, Jones, David, (2006) “A Model of Customer Satisfaction and Retention for Hotels", Journal of Quality Assurance in Hospitality \& Tourism 7(3), s. 1-23.

Suki, Norazah, Mohd, (2014) "Moderating Role of Gender in the Relationship Between Hotel Service Quality Dimensions and Tourist Satisfaction", Journal of Quality Assurance in Hospitality \& Tourism 15, s. 44-62.

Şimşek, Hüseyin, (2009) "Eğitim Tarihi Araştırmalarında Yöntem Sorunu”, Ankara Üniversitesi Eğitim Bilimleri Fakültesi Dergisi 42(1), s. 33-51.

Şirin, Mustafa Emre, Aksu, Murat, (2016) “Otel İşletmelerinde Hizmet Kalitesinin Müşteri Memnuniyeti, Tekrar Satın Alma ve Tavsiye İsteği Üzerine Etkisi: Trabzon Ortahisar Örneği”, Karabük Üniversitesi Sosyal Bilimler Enstitüsü Dergisi, 6(2), s. 530-544.

Tarhan, Özge, (2015) "Sosyal Bilgiler Öğretmeni Adaylarının Politik Okuryazarlığa İlişkin Görüşleri”, Akademik Sosyal Araştırmalar Dergisi 3(9), s. 649-669.

T.C. Kültür ve Turizm Bakanlığı, Yatırım ve İşletmeler Genel Müdürlüğü, “Turizm İşletme Belgeli Tesisler”, son erişim tarihi: 10.01.2019, https://yigm.ktb.gov.tr/TR-9579/turizm-tesisleri.html.

Torres, Edwin N., Fu, Xiaoxiao, Lehto, Xinran, (2014) "Examining Key Drivers of Customer Delight in a Hotel Experience: A Cross-Cultural Perspective", International Journal of Hospitality Management 36, s. $255-262$.

Warrens, Matthijs J., (2014) "New Interpretations of Cohen's Kappa”, Journal of Mathematics ID: 203907, s. 1-9.

Yılmazdoğan, Orhan Can, Özel, Çağıl Hale, (2014) "Sosyal Medya Pazarlamasının Otellerdeki Kullanımının Yararlarına Yönelik Yönetici Algılarının Belirlenmesi: Antalya Örneği”, İşletme Fakültesi Dergisi 15(1), s. 37-62. 